\title{
Trace elements and isotope data of the Um Garayat gold deposit, Wadi Allaqi district, Egypt
}

\author{
Basem Zoheir ${ }^{1,2, *}$, Ashraf Emam ${ }^{3}$, Iain K. Pitcairn ${ }^{4}$, Arman Boskabadi $^{5}$, Yann Lehaye $^{6}$, \\ Matthew J. Cooper ${ }^{7}$
}

${ }^{1}$ Department of Geology, Faculty of Science, Benha University, 13518 Benha, Egypt

${ }^{2}$ Institute of Geosciences, University of Kiel, Ludewig-Meyn Str. 10, 24118 Kiel, Germany ( ${ }^{*}$ corresponding author: basem.zoheir@gmail.com)

${ }^{3}$ Department of Geology, Faculty of Science, Aswan University, 81528 Aswan, Egypt

${ }^{4}$ Department of Geological Sciences, Stockholm University, 10691 Stockholm, Sweden ${ }^{5}$ Department of Geological Sciences, University of Texas, Dallas, USA

${ }^{6}$ Finland Isotope Geosciences Laboratory, Geological Survey of Finland, Espoo, Finland

${ }^{7}$ National Oceanography Centre Southampton, University of Southampton, Southampton, UK

\begin{abstract}
Trace element composition of sulfides and $\mathrm{O}, \mathrm{C}, \mathrm{Sr}$ and $\mathrm{S}$ isotopic data are assessed to constrain the evolution and potential fluid and metal sources of the Um Garayat gold deposit. Ore microscopy and BSE investigations of quartz veins show blocky arsenopyrite and pyrite replaced in part by pyrrhotite, chalcopyrite, sphalerite, galena, and gersdorffite. Free-milling gold occurs commonly in close association with the late sulfides, and along fractures in pyrite. On the other hand, recrystallized pyrite is disseminated in host metavolcaniclastic/metasedimentary rocks that commonly contain carbonaceous material. In-situ LA-ICP-MS analysis of sulfides show the recrystallized pyrite enriched in most trace elements, while blocky pyrite contains only some traces of arsenic. Detected concentrations of gold (up to $17 \mathrm{ppm}$ ) were only reported in arsenopyrite disseminated in quartz veins.

The $\delta^{34} \mathrm{~S}$ values of blocky pyrite and pyrrhotite in quartz veins define a narrow range (1.6 to $3.7 \%$ ), suggesting a homogenous sulfur source which is consistent with the dominantly mafic host rocks. The recrystallized pyrite has a distinctive sulfur isotope composition ( $\delta^{34} \mathrm{~S}-9.3$ to $-10.6 \% 0$ ), which is rather comparable to diagenetic sulfides. Hydrothermal carbonate in quartz veins and wallrock have nearly constant values of $\delta^{18} \mathrm{O}(10.5$ to $11.9 \%)$ and $\delta^{13} \mathrm{C}(-4.2$ to $-5.5 \%)$. Based on constraints from mineral assemblages and chlorite thermometry, data of six samples indicate that carbonate precipitation occurred at $\sim 280^{\circ} \mathrm{C}$ from a homogenous hydrothermal fluid with $\delta^{18} \mathrm{O}_{\mathrm{H} 2 \mathrm{O}} 4.4 \pm 0.7 \%$ and $\delta^{13} \mathrm{C}=-3.7 \pm 0.8 \%$. Strontium isotope values of two samples $\left({ }^{87} \mathrm{Sr} /{ }^{86} \mathrm{Sr}=0.7024\right.$ and 0.7025$)$ are similar to the initial ${ }^{87} \mathrm{Sr} /{ }^{86} \mathrm{Sr}$ ratios of island arc metabasalts $(\sim 710 \mathrm{Ma})$ in the South Eastern Desert. The generally homogenous sulfur, $\mathrm{C}, \mathrm{O}, \mathrm{Sr}$ isotope data are suggestive of metamorphogenic fluids, likely produced from dominantly mafic volcanic rocks at the greenschist-amphibolite facies transition.
\end{abstract}

\section{Keywords:}

Um Garayat gold deposit, Wadi Allaqi, South Eastern Desert of Egypt, Isotope C, $O$ and Sr data of carbonate, EPMA and LA-ICP-MS data of sulfides, Ore genesis 
50 Egypt has a long history of gold mining dating back to the times of Pharaohs, although most of the historical mines remained abandoned for the entire second half of the $20^{\text {th }}$ century. The only currently active gold mine is the Sukari deposit with an annual production of about half a million ounces $\mathrm{Au}$ and a resource of $\sim 15 \mathrm{Moz}$. The fact that this deposit remained abandoned for tens of years reflects the untapped potential of gold resources in Egypt.

The Allaqi-Heiani belt in the Neoproterozoic Nubian Shield of the South Eastern Desert of Egypt is an about $50 \mathrm{~km}$-wide zone of deformation associated with an extensive, $\sim 250 \mathrm{~km}$-long WNW-ESE fold-and-thrust belt (Fig. 1; Abdelsalam and Stern 1996, Abdelsalam et al. 2003, Zoheir and Klemm 2007). The Wadi Allaqi district contains numerous occurrences of gold mineralization, among which the Um Ashira, Hariari, Naguib, Nile Valley Block, Marahiq, Atshani, Feilat, and Wadi Murra occurrences, and Haimur and Um Garayat mines are widely known historical $\left(7^{\text {th }}\right.$. $11^{\text {th }}$ centuries) localities. Controls and genesis of gold-bearing quartz veins in most of these occurrences are either not addressed or poorly constrained so far.

The Um Garayat gold deposit was sporadically mined until 1948 (Ivanov and Hussein 1972). Gold mineralization is expressed in sulfide-rich quartz and quartzcarbonate veins cutting through variably deformed island arc metavolcanic and metavolcaniclastic rocks. Although considered the most important among all occurrences in the Wadi Allaqi district, little is known about this deposit. In this study, new EPMA and LA-ICP-MS data are used to reveal the evolution of the mineralization process. In situ $S$ isotope measurements, and $\delta^{18} \mathrm{O}, \delta^{13} \mathrm{C}$, and ${ }^{87} \mathrm{Sr} /{ }^{66} \mathrm{Sr}$ systematics of carbonate from mineralized quartz veins and altered wallrocks are used to place constraints on the source of the ore fluids. We suspect that a wellconstrained genetic model of gold in the region can help developing a more efficient exploration program.

\section{The Wadi Allaqi district}

79

80

81

82

83

84

85

86

87

88

89

90

91

92

93

94

\section{Geological setting}

Wadi Allaqi is the largest wadi in the South Eastern Desert, where it extends for more than $270 \mathrm{~km}$ along a NW-SE axis, from the Red Sea Hills to its downstream confluence with the Nile Valley east of Lake Nasser. The Wadi Allaqi district is underlain by a variety of rock types; including carbonatized ophiolites, island arc metavolcanic/volcaniclastic rocks and arc-related gabbro-diorite intrusions, synorogenic tonalite-granodiorites and late-orogenic mozo/syenogranites (Fig. 2; e.g., Abdelsalam et al. 2003). Gneissic rock terranes, mainly of paragneisses, occur west or south of the allochthonous supracrustal nappes (Finger and Helmy 1998; Abd ElNaby and Frisch 2002).

The ophiolitic rocks form disrupted, allochthonous and discontinuous blocks of serpentinite, highly serpentinized metapyroxenite and metagabbro tectonically embedded in a matrix of foliated metavolcanic/metasedimentary rocks. The geochemical characteristics and spinel composition of relict pyroxenite from the Allaqi belt suggest a fore-arc setting (Khalil et al. 2014). According to Ali et al. (2010), 


\section{5}

116

the age of ophiolite formation in Wadi Allaqi is constrained by layered gabbro which gave a $\mathrm{U}-\mathrm{Pb}$ zircon Concordia age of $730 \pm 6 \mathrm{Ma}$, while the timing of ophiolite emplacement is demarcated by the Um Ashira quartz-diorite intrusion (709 $\pm 4 \mathrm{Ma}$ ).

The island-arc rocks are represented by a group of schistose basic to intermediate metavolcanics and volcaniclastic metasedimentary rocks. Metabasalt, meta-andesite, metadacite, metatuffs, chlorite talc schist and biotite-chlorite schist are the main units of this group. Thrust faulting extending NW-SE delineates the contact between the ophiolites and island arc rocks. Geochemical data of the metavolcanic rocks reveal their low to medium-K, calc-alkaline to tholeiite nature, suggesting an immature island arc setting (Emam et al. 2014). El Nisr (1997) suggested a transitional environment between continental arc and continental margin for the intermediate members of these metavolcanics.

Gabbro-diorite intrusions, assumed to belong to the island-arc assemblage, are heterogeneous in composition and are locally foliated and contain xenoliths of metavolcanic rocks (Noweir et al. 1996). Extensive syn-orogenic granodiorite intrusions cut the ophiolitic and island arc terranes, and generally form low relief pertaining to severe weathering. Late-orogenic granitic intrusions, on the other hand, form conspicuous peaks of pink granites cutting the pre-existing island arc and gabbro-diorite rocks.

\section{Structural evolution and metamorphism}

The Wadi Allaqi district contains the western part of the Allaqi-Heiani belt in the South Eastern Desert. This belt was developed through a four-phase deformation history (Table 1), in which an early N-S to NNE-SSW regional shortening led to development of SSW-verging folds and NNE dipping thrusts (e.g. Abdelsalam and Stern 1996; Abdelsalam et al. 2003 and references therein). The shortening fabrics are imposed by NNW-SSE oriented folds and major wrench faults/shear zones, generally showing left-lateral displacement. These deformation events are interpreted as an early terrane accretion along the Allaqi-Heiani through basin closure above a north-dipping subduction zone; and a later collision between Eastand West-Gondwana at ca. 750-650 Ma (Kusky and Ramadan 2002 and references therein). The late collision deformed the Allaqi-Heiani belt along $\mathrm{N}-\mathrm{S}$ trending shortening zones and produced NW-SE sinistral and NE-SW dextral transpressional faults (Zoheir and Klemm 2017). Abdeen and Abdelghaffar (2011) suggested that the late collision phase was related to the Neoproterozoic Najd orogen (640-550 Ma).

In the Wadi Allaqi district, a regional variation in metamorphic grade is observed in the allochthonous ophiolitic belt and the tectonically lower island arc rocks and gneisses. A greenschist mineral assemblage, i.e., chlorite, tremolite-actinolite, albite and epidote is common in the ophiolitic and island arc metavolcanic rocks. High grade metamorphic conditions are manifested by garnet and fibrous sillimanite in pelitic bands west of Wadi Shelman (El-Kazzaz 1995). The Abu Swayel metasedimentary succession comprises hornblende gneiss, garnet-biotite gneiss and marble bands (El Shazly et al. 1973, Hassan and Hashad 1990). The sillimanitegarnet-hornblende-biotite assemblage of the $\mathrm{Abu}$ Swayel paragneisses reflects amphibolite facies metamorphism $\left(560^{\circ} \mathrm{C}, 5.5-6.3 \mathrm{kbar}\right.$; Abd El-Naby and Frisch 2002). 
In the central part of the Allaqi-Heiani belt, Zoheir and Klemm (2007) calculated conditions of $534-561^{\circ} \mathrm{C}$ and 5.3-6.2 kbar, under which garnet, staurolite and sillimanite were formed. They suggested that peak metamorphism was attained during the second phase of deformation (D2), which was a phase of NW-folding and mineral foliation in response to an E-W compressional regime.

Abd El-Naby et al. (2000) suggested that metamorphism occurred during terrane collision and ophiolite emplacement. Finger and Helmy (1998) suggested that the high-grade paragneisses in the Abu Swayel area were formed during collisional crustal thickening, when a Pan-African terrane assembly was attached to the eastern Sahara Craton at $\sim 650-600 \mathrm{Ma}$. Abd El-Naby and Frisch (2002) suggested that the protolithic sediments of the Wadi Haimur-Abu Swayel gneisses were evolved in a back-arc basin. Biotite in migmatized gneisses gave a K/Ar age of $\sim 585 \mathrm{Ma}$, which is interpreted as the cooling age following peak metamorphic conditions (Abd El-Naby and Frisch 2002). The upper age of metamorphism of the Wadi Haimur ophiolites is based on similar $\mathrm{Sm} / \mathrm{Nd}$ ages of clinopyroxene and hornblende (ca. $630 \mathrm{Ma}$ ), while a younger Sm/Nd age for a garnet-bearing rock ( $c a .590 \mathrm{Ma}$ ) is interpreted as the cooling age (Abd El-Naby et al. 2000).

\section{Gold metallogeny}

Gold mining in the Wadi Allaqi district was active during the Egyptian Empire times (New Kingdom 1550-1070 BC; Klemm et al. 2001; Klemm and Klemm 2013). Gold localities range from small occurrences of $\mathrm{Au}$-bearing quartz veins to large mines with underground workings (Fig. 2). El-Kazzaz (1995) suggested that mineralized quartz veins in the district are controlled by brittle-ductile shear zones, and dilation sites were created by movements along undulating and irregular foliation planes in the central part of the shear-zones. The sigmoidal and boudinaged quartz veins led him to assume vein formation during the infinitesimal strain stages of D1. Similarly, Kusky and Ramadan (2002) suggested a mutual association between gold-quartz veins and the imbricate thrust slices of ultramafic rocks, and shear zones truncating the ophiolitic rocks. Klemm et al. (2001) suggested that metasedimentary and acidic metavolcanic rocks cut by granitoid intrusions, is the preferable setting of gold in the district. On the other hand, Osman (2014) evoked that gold-bearing quartz veins show no association with any phase of magmatic activity in the region.

El-Shimi (1996) assumed that gold-bearing shear zones in the central Allaqi belt truncate large synclines associated with huge ophiolitic blocks and highly sheared metavolcanic rocks. Ramadan et al. (2005) reported gold-bearing alteration zones delineating tight or overturned NW-anticlines. According to Zoheir (2004, 2008a,b), formation of the gold-bearing quartz veins in the central Allaqi-Heiani belt was synkinematic with the development of post-peak metamorphism D3-related NW- and NNW- ductile shear zones. Zoheir and Emam (2014) described gold-bearing quartz and quartz-carbonate veins confined to listvenite exposures at Haimur mine, commonly controlled by NE-trending shear zones.

Preliminary geochemical surveys revealed the presence of mineralized (several ppm of $\mathrm{Au}$ ) hydrothermal alteration zones within and outside the old mining sites in the Wadi Allaqi district (e.g., Oweiss and Khalid 1991; Ramadan et al. 2001; Kusky 
and Ramadan 2002). El-Makky (2011) carried out a lithogeochemical study at the Um Garayat mine area and noticed that the light REE and Au show similar dispersion patterns in the alteration zones.

\section{The Um Garayat gold deposit}

The Um Garayat mine area is underlain by metavolcanic and metasedimentary rocks, strongly foliated in places and cut by metagabbro-diorite and granodiorite-tonalite intrusions (Fig. 3). The metavolcanic rocks comprise meta-andesite, meta-andesitic tuffs, metadacite, and meta-rhyolitic tuffs (Fig. 3). Metagreywacke, metasiltstone and metamudstone, with local intercalations of graphite schist, marble and quartzite are less common. Andesite, diorite, and trachyte dykes as well as quartz veins, veinlets, and lenses cut the host rocks in several directions.

Gold-bearing quartz veins are hosted by sheared silty and graphite-bearing metasedimentary and tuffaceous rocks. Most of the veins strike $\mathrm{N} 30^{\circ} \mathrm{W}$ and dip $70^{\circ}$ to NE (Fig. 3). Some of the mineralized veins extend for more than $1 \mathrm{~km}$, and have a width of up to $1.8 \mathrm{~m}$ in the swelling zones (e.g., Sabet et al. 1983; Ivanov 1988; ElMakky 2000). Adjacent to the gold-bearing quartz veins, pervasive sulfidation is manifested by impregnations of chalcopyrite, covellite, chalcocite, and pyrite in the altered wallrocks (e.g., Oweiss and Khalid 1991).

Gold content varies significantly in the mineralized quartz veins, from 7 to 156 ppm (El Ramly et al. 1970; Sabet et al. 1983). However, the average grade of the worked quartz veins is suggested to have been $\sim 10-13 \mathrm{ppm}$, and the high grade ores were encountered at depths of 30 to $40 \mathrm{~m}$ below surface (Klemm and Klemm 2013). Oweiss and Khalid (1991) carried out a surface geochemical mapping of I km² surrounding the Um Garayat mine area at the scale of 1:2000. They identified NNWand N-trending alteration zones of silicified and carbonatized wallrock, with measurable contents of gold (up to $6 \mathrm{ppm}$ ). The main quartz vein (NNW-SSE) is associated with discrete silicification zones, and is displaced by $\sim \mathrm{E}-\mathrm{W}$ faults.

The wadi workings and scattered millstones northward of the settlements at Um Garayat mine area may refer to extensive small-scale gold mineralization in the area. Magnetic anomalies overlapping with an alteration zone in metavolcanic rocks east of the Um Garayat mine led Hussein (1990) to propose the presence of a buried ore body. Core samples from a 212 m-deep borehole showed the presence of a thick body of massive sulfides beneath a $\sim 70$ meter-thick layer of altered metavolcanic rocks (Hussein 1990). Ramadan et al. (2001) used Landsat-5 TM and SIR-C/X-SAR data to map the hydrothermal alteration associated with the Um Garayat and Marahiq gold deposits. They identified silicification, chloritization, and ferrugination zones south of the Um Garayat gold mine and determined Au contents of up to $3 \mathrm{ppm}$ in quartz veins cutting these alteration zones. Ramadan and Sultan (2003) reported magnetic susceptibility anomalies of $954 \times 10^{-6} \mathrm{emu}$ at a depth from $\sim 40$ to $139 \mathrm{~m}$, and half widths of tens to hundreds of meters southeast of the Um Garayat gold mine and in Wadi Rilan. They suggested that these anomalies coincide with buried massive sulfide ores. 
The mineralized quartz veins and sulfidized wallrocks were sampled to study the ore mineralogy, paragenesis and isotopic composition of hydrothermal ore and gangue minerals. Sample locations are shown in Fig. 3, and a brief description is given in ESM

\section{Microprobe analysis}

253

254 Table 1. Samples collected from the dump at the mine shaft are found richer in disseminated sulfides than samples collected from the surface exposures. Systematic sampling from the underground mine works was not possible due to the damage of the adits and the status of the inclined shafts. Comparison between surface samples from quartz veins and those collected from the mine dump aided understanding of the nature and composition of the ore-forming fluids. In many cases, the ore bodies comprise quartz and quartz-carbonate veins and intensely sulfidized and carbonatized wallrock.

\section{Methods}

Petrographic investigations were aided by SEM back-scattered electron imaging. Chemical composition of sulfides, hydrothermal silicate and carbonate minerals in selected samples was determined on polished thin sections using a SX-50 Cameca instrument at the University of Lausanne, Switzerland. Operating conditions for sulfides were a $20 \mathrm{kV}$ accelerating voltage, a $30 \mathrm{nA}$ beam current $(1 \mu \mathrm{m}$ focused beam), and counting times of 10 to $100 \mathrm{~s}$. For sericite, chlorite and carbonate, the operating conditions were $15 \mathrm{kV}$, with a beam current of 10 to $20 \mathrm{nA}$, a beam size of $1 \mu \mathrm{m}$, and counting times of $20 \mathrm{~s}$. The used standards were silicates, oxides, and pure elements.

264 Laser ablation single collector ICP-MS analyses of sulfide minerals were performed at the Geological Survey of Finland (GTK), using a Nu AttoM SC-ICPMS (Nu Instruments Ltd., Wrexham, UK) and an Analyte 193 ArF laser-ablation system (Photon Machines, San Diego, USA). The laser was run at a pulse frequency of $5 \mathrm{~Hz}$ and pulse energy of 3 $\mathrm{mJ}$ at $30 \%$ attenuation to produce an energy flux of $1.68 \mathrm{~J} / \mathrm{cm}^{2}$ on the sample surface with a $50 \mu \mathrm{m}$ spot size. The laser was automatically switched on for 60 seconds for signal acquisition and then off for 20 seconds for background levels to be attained and measured. Analyses were made using time resolved analysis (TRA) with continuous acquisition of data for each set of points (2 standards, 10 unknown sulfide, 4 quality control standards). The Standard MASS-1 has been pressed into a nano-particulate pressed pellet (Garde-Schönberg et al. 2014) and its compiled concentrations from Wilson et al. (2002) and Yuan et al (2012) have been used for external standardization. ${ }^{33} \mathrm{~S}$ has been used, as an internal standard for the quantification of the sulfide minerals. The measurements were performed over 28 elements at low resolution $(\Delta \mathrm{M} / \mathrm{M}=300)$ using the fast scanning mode. Data reduction was handled using the software GLITTER TM (Van Achterbergh et al. 
2001) that allows the baseline subtraction, the integration of the signal over a selected time resolved area and the quantification using known concentrations of the external and internal standards.

\section{In situ sulfur isotope analysis of sulfide minerals by LA-ICP-MS}

Sulfur isotope analyses of pyrite were carried out using a $\mathrm{Nu}$ Plasma HR multicollector ICPMS at the Geological Survey of Finland in Espoo together with a Photon Machine Analyte G2 laser microprobe. Samples were ablated in He gas (gas flows $=0.4$ and $0.1 \mathrm{l} / \mathrm{min}$ ) within a HelEx ablation cell (Müller et al. 2009). $\mathrm{S}$ isotopes were analyzed at medium resolution. During the ablation the data were collected in static mode $\left({ }^{32} \mathrm{~S},{ }^{34} \mathrm{~S}\right)$. Single spot Py samples were ablated at a spatial resolution of $30 \mu \mathrm{m}$, using a fluence of $2.2 \mathrm{~J} / \mathrm{cm}^{2}$ at $4 \mathrm{~Hz}$. The total $\mathrm{S}$ signal obtained for pyrite was typically $2 \mathrm{~V}$. Under these conditions, after a $20 \mathrm{~s}$ baseline, 30-50 $\mathrm{s}$ of ablation is needed to obtain an internal precision of ${ }^{34} \mathrm{~S} /{ }^{32} \mathrm{~S} \leq \pm 0.000005(1 \sigma)$. Two pyrite standards have been used for external standard bracketing (PPP-1; Gilbert et al. 2014) and quality control (in-house standard Py1) of analyses. The in-house standard Py1 has been previously measured by gas mass spectrometry. For a $\delta^{34} \mathrm{~S}$ (CDT) value of $-0.6 \pm 0.6 \%$ ( $1 \sigma$ ) for Py1 we have found an average value of $-1.1 \pm$ $0.44 \% 0(2 \sigma, n=11)$. Part of the difference in accuracy is related to the in house standard homogeneity. Chalcopyrite was ablated at a spatial resolution of $30 \mu \mathrm{m}$, using a fluence of $2.7 \mathrm{~J} / \mathrm{cm}^{2}$ at $5 \mathrm{~Hz}$, depending on sensitivity. The total S signal obtained for chalcopyrite was typically $1.2 \mathrm{~V}$. Under these conditions, after a $20 \mathrm{~s}$ baseline, 30-40 s of ablation is needed to obtain an internal precision of ${ }^{34} \mathrm{~S} /{ }^{32} \mathrm{~S} \leq \pm$ $0.00005(1 \sigma)$. Two in-house chalcopyrite standards have been used for external standard bracketing and quality control of analyses. Those standards have been measured by gas mass spectrometry. For a $\delta^{34} \mathrm{~S}(\mathrm{CDT})$ value of $-0.7 \pm 0.5 \%$, we have found an average value of $-0.53 \pm 0.46 \% 0(2 \sigma, n=7)$.

\section{Stable isotope analysis ( $\mathrm{C}$ and $\mathrm{O}$ )}

Carbon and oxygen isotope analyses were carried out on nine carbonate samples. Carbonate powders were prepared by micro-milling of carbonate veins. Sample powders were analyzed for $\delta^{13} \mathrm{C}$ and $\delta^{18} \mathrm{O}$ at the Stable Isotope Laboratory (SIL) of the Department of Geological Sciences at Stockholm University. Sample aliquots corresponding to $0.25 \mathrm{mg}$ carbonate were reacted with excess of $100 \%$ phosphoric acid at $100^{\circ} \mathrm{C}$ for one hour before analysis of $\mathrm{CO}_{2}$ using a Gasbench II connected to a MAT253 IRMS both from Thermo Scientific. Repeat analysis of NBS18, IAEA-CO-1 and IAEA-CO-8 standards and two controls gives standard deviations better than 0.1 $\%$ for $\delta^{13} \mathrm{C}$ and $0.15 \%$ for $\delta^{18} \mathrm{O}$. The $\delta^{18} \mathrm{O}$ values of samples prepared at $100^{\circ} \mathrm{C}$ were analyzed with a dolomite oxygen isotopic fractionation factor of 1.00901 (Rosenbaum and Sheppard 1986). For normalization of the $\delta^{18} 0$ results, we used two IAEA standards ranging from a $\delta^{18} \mathrm{O}$ VPDB value of $-2.44 \%$ (IAEA-CO-1; Brand et al. 2014) to a $\delta^{18} \mathrm{O}$ (VPDB) value of $-23.01 \%$ (NBS18; Verkouteren and Klinedinst 2004). 
$325 \mathrm{Sr}$ isotope analysis was carried out at the National Oceanography Centre 326 Southampton (NOCS). Dolomite bearing samples were digested in sub-boiled 2M $\mathrm{HNO}_{3}$ at $130^{\circ} \mathrm{C}$ for 48 hours. The mother solutions were subsampled to give approximately $1 \mu \mathrm{g} \mathrm{Sr}$ and the Sr was isolated using $50 \mu \mathrm{l} \mathrm{Sr}$-Spec resin columns; the column blanks were $<0.1 \mathrm{ng}$. The dried samples were loaded onto a single Ta filament with a Ta activator solution. ${ }^{87} \mathrm{Sr} /{ }^{86} \mathrm{Sr}$ was analyzed on a Thermo Fisher Scientific Triton Plus Thermal Ionisation Mass Spectrometer with a beam size of ${ }^{88 \mathrm{Sr}}$ $=2 \mathrm{~V}$ and normalized to ${ }^{86} \mathrm{Sr} /{ }^{88} \mathrm{Sr}=0.1194$ using an exponential fractionation

\section{Results}

338

\section{Ore mineralogy}

340 Ore microscopy of the gold-bearing quartz veins and altered wallrock reveals the 341 presence of disseminated pyrite, arsenopyrite, pyrrhotite, and subordinate amounts of chalcopyrite sphalerite, galena and free gold. The sulfide minerals are most abundant in sheared wallrocks and in sericite-carbonate-rich wallrock slivers and ribbons enclaved in the quartz veins. Hydrothermal mineral phases in addition to sulfide minerals comprise quartz, carbonate, sericite, chlorite, and rutile. In some samples, carbonaceous material is confined to serrate grain boundaries between ribboned and recrystallized quartz.

Pyrite and arsenopyrite are ubiquitous in the mineralized quartz veins and altered wallrocks. Pyrite in sample G7 occurs as coarse-grained euhedral or subeuhedral crystals, commonly with porous or ragged surfaces, and devoid of any inclusions of other sulfide minerals (Fig. 4a). Recrystallization and crystal growth is observed in the large euhedral crystals, with the primary phase being represented by colloform or porous pyrite and well-crystalline euhedral cores being the recrystallized phase (Figs. 4a,b). Hydrothermal pyrite is disseminated in quartz veins and altered wallrocks. The textural relationship between the recrystallized and hydrothermal pyrite phases is not clear as no direct contact or overlap is observed in the investigated samples. The hydrothermal pyrite has a distinct blocky, massive appearance, and locally contains euhedral arsenopyrite inclusions (Figs. 4c-e). It is replaced by pyrrhotite or adhered to other pyrite crystals by galena and chalcopyrite (Fig. 4d). Arsenopyrite forms large prismatic crystals, commonly intergrown with pyrite or occurs as fine euhedral inclusions in pyrite and pyrrhotite (Figs. 4c-f). Pyrrhotite and chalcopyrite replace euhedral crystals of arsenopyrite commonly from cores (Fig. 4g). Sphalerite is rarely associated with pyrrhotite and chalcopyrite 364 (Fig. 4f). In a few samples, gersdorffite intergrowth with chalcopyrite and galena replaces subhedral pyrite crystals (Fig. 4h). Visible free gold occurs as fine specks and blebs, commonly associated with sericite, chlorite and carbonate minerals throughout the small ribbons of wallrocks and microfactures in quartz veins and in fractured pyrite (Fig. 4i). 
Back-scattered electron images show that gold or electrum specks are confined to the microfractures in arsenopyrite or along boundaries between arsenopyrite and pyrite (Figs. 5a,b). In pyrite, free gold particles occur commonly in association with chalcopyrite or gersdorffite (Figs. 5c,d). The microscopic and BSE investigations allow us to reconstruct a two-fold paragenetic sequence, in which the gold-sulfide mineralization overprints 'diagenetic' pyrite that is only disseminated in the host metasedimentary rocks (Fig. 6)

The EPMA data of pyrite (ESM Table 2) show trace concentrations of Ni (up to 0.3 wt\%), As (up to $0.29 \mathrm{wt} \%$ ), and Co (up to $0.76 \mathrm{wt} \%$ ). No optical or compositional zoning was observed. The recrystallized pyrite in sample G7 is characterized by traces of $\mathrm{Ni}$, while blocky hydrothermal pyrite in quartz veins is characteristically Asbearing. Arsenopyrite has a near to stoichiometric composition (ESM Table 2), with a S-rich formula (Fe1-1.03As0.85-0.96 $\mathrm{S}_{1.02-1.12}$ ). Most trace elements in arsenopyrite are at or below detection, with the exception of some traces of $\mathrm{Sb}$ in a few cases. Euhedral and subhedral arsenopyrite crystals show weak zoning with variable S/As ratios ( 0.46 to 0.56 ). The arsenic content varies from 40.6 to $44.0 \mathrm{wt} \%$, which correspond to $28.6-32.1$ at $\%$ and indicate formation temperatures of $\leq 360^{\circ} \mathrm{C}$, ave. $340^{\circ} \mathrm{C}$ (Kretschmar and Scott 1976).

\section{Alteration mineralogy}

390

391

392

393

394

395

396

397

398

399

400

401

402

403

404

405

406

407

408

409

410

The common occurrence of quartz, sericite, chlorite, and rutile in wallrocks and quartz veins associated with disseminations of pyrite, pyrrhotite, and arsenopyrite implies a mutual relationship between hydrothermal alteration and gold mineralization. Extensive carbonate alteration in mafic tuffaceous rocks is observed even beyond the mine area. The gold-bearing quartz veins are associated with a few $\mathrm{cm}$-wide zones of silicified wallrocks. In the underground work, carbonatized metaagglomerate and metasiltstone are characterized by abundant pyrite and arsenopyrite. Sericite and rutile form laths in metagreywacke and in the quartz veins (Fig. 7a). Carbonaceous material occurs in slivers of metasiltstone or as ribbons within the mineralized quartz veins in association with chlorite, carbonate, and sulfide disseminations (Fig. 7b).

Chlorite compositions in quartz veins and wallrocks immediately adjacent to quartz veins are consistent, mostly constrained to pycnochlorite and less commonly ripidolite. Chlorite analyzed contains low to intermediate concentrations of $\mathrm{MnO}$ ( 0.23 to $1 \mathrm{wt} \%$ ). The calculated structural formulae of chlorite flakes (on the basis of 28 oxygen) show slight variation in the contents of Si 5.56 to 5.78 apfu, $\mathrm{Fe}^{2+} 3.03$ to $3.56 \mathrm{apfu}$, Mg 5.70 to $6.14 \mathrm{apfu}$, and Alt 4.51 to 5.06 apfu (ESM Table 3). The AlVI and AlV abundances of chlorite are negatively correlated. $\mathrm{Fe} /(\mathrm{Fe}+\mathrm{Mg})$ ratios are nearly constant ( 0.35 to 0.38 ). Chlorite temperatures based on Al-content in the tetrahedral site of chlorite according to the method of Kranidiotis and Maclean (1987) are in the range of $282-304^{\circ} \mathrm{C}$ (Table 4). Similar estimations are attained when applying equation 38 in (Lanari et al. 2014).

Sericite composition (ESM Table 4) has relatively low concentrations of $\mathrm{FeO}$ (1.9$2.35 \mathrm{wt} \%), \mathrm{MgO}$ (1.15-1.84 wt\%), $\mathrm{TiO}_{2}$ (0.10-0.23 wt\%) and $\mathrm{Na}_{2} \mathrm{O}$ (0.11-0.27 wt\%). The calculated structural formula of sericite, calculated on basis of 22 anions, shows consistent compositions essentially of tetrahedral Si (6.29-6.69 apfu), Al ${ }^{\mathrm{IV}}$ (1.31-1.71 
apfu), $\mathrm{Al}^{\mathrm{VI}}$ (3.44-3.61 apfu) and $\mathrm{K}$ (1.63-1.76 apfu). The (Mg, Fe) and Na contents are all low (generally bellow 0.5 apfu.). Carbonate minerals, Fe-dolomite and less common calcite, are intergrown with quartz and sericite in quartz veins, or occur as veinlets in the altered host rocks. Calcite is nearly pure, with almost all analyses containing $>96$ mole $\% \mathrm{CaCO}_{3}$. Sr, and $\mathrm{Ba}$ are at or below the limit of detection in all samples, but showed measurable levels of $\mathrm{Mg}, \mathrm{Mn}$, and Fe. Dolomite shows variable contents of $\mathrm{FeO}$ (4.4-8.1 wt\%) and $<50$ mole \% combined Mg, Mn, and Fe (ESM Table 4). The EPMA data indicate that carbonate in the altered host rocks and in quartz veins pertain to the dolomite-ankerite series. The BSE investigation reveals that carbonate patches in quartz veins have magnesium-rich central parts, and iron-rich peripheral zones.

\section{Trace element concentrations in sulfides}

In situ laser ablation ICP-MS analyses were carried out on pyrite, arsenopyrite, pyrrhotite and chalcopyrite in four mineralized samples. Mean, maximum, minimum values are reported in ESM Table 5 and the full set of analyses is available in ESM Table 5A. Here we describe the variations in the main elements of interest; As, Se, $\mathrm{Mo}, \mathrm{Ag}, \mathrm{Sb}, \mathrm{Te}, \mathrm{W}, \mathrm{Au}$ and Bi. Many of these elements are heterogeneously distributed with values ranging from the limits of detection up to several 1000s of ppm (ESM Table 5).

Recrystallized pyrite in the carbonatized metasiltstone with carbonaceous laminae (sample G7) has noticeable contents of Cu (up to $2881 \mathrm{ppm}$ ), Ni (up to 1212 ppm), Co (up to $997 \mathrm{ppm}$ ), Pb (up to $829 \mathrm{ppm}$ ), As (up to $308 \mathrm{ppm}$ ), Se (up to 181 ppm), Zn (up to $49 \mathrm{ppm}$ ), Te (up to $37 \mathrm{ppm}$ ), Bi (up to $31 \mathrm{ppm}$ ) and Ag (up to 23 ppm). Gold contents in this pyrite variety are less than $1 \mathrm{ppm}$ or below the detection limit. The single analysis in which the Au content measures $0.98 \mathrm{ppm}$ is enriched in most trace elements (Co, $\mathrm{Ni}, \mathrm{As}, \mathrm{Se}, \mathrm{Ag}$, Te, and $\mathrm{Bi}$ ) compared to the analyses in which $\mathrm{Au}$ is absent or very low. In sample $22 \mathrm{~b}$, the weakly recrystallized pyrite shows high concentrations of As (up to 2614 ppm), Pb (max. 1125 ppm), Co (max. 464 ppm), Sb (max. 303 ppm), Se (max. 154 ppm), Ni (max. 138 ppm), Cu (max. 77 ppm), Zn and Hg (max. $23 \mathrm{ppm}$ ). Molybdenum, Cr and V concentrations are still measurable (up to $20 \mathrm{ppm})$, while gold content is very low $(\leq 0.2 \mathrm{ppm})$.

The massive blocky pyrite in samples G4 and G5 is characterized by some concentrations of As (up to $3573 \mathrm{ppm}$ ), $\mathrm{Zn}$ (up to $1339 \mathrm{ppm}$ ), $\mathrm{Cu}$ (up to $1234 \mathrm{ppm}$ ), $\mathrm{Pb}$ (up to $587 \mathrm{ppm}$ ), Ni (up to $184 \mathrm{ppm}$ ), Se (up to $69 \mathrm{ppm}$ ), Sn (up to $60 \mathrm{ppm}$ ), V (up to $41 \mathrm{ppm}$ ), and Co (up to $54 \mathrm{ppm}$ ). The $\mathrm{Au}, \mathrm{Mo}, \mathrm{Ag}, \mathrm{Te}, \mathrm{Sb}, \mathrm{W}$ and Bi contents are very low or below the detection limit.

Arsenopyrite in quartz veins (sample G4 and G5) contains some Sb (up to 530 $\mathrm{ppm}$, mean $=233 \mathrm{ppm}$ ) and up to $16.9 \mathrm{ppm} \mathrm{Au}$ (ave. Au is $6.9 \mathrm{ppm}$ ). It contains lower Se $($ mean $=89 \pm 36 \mathrm{ppm})$, Co $($ mean $=28 \pm 40 \mathrm{ppm})$, Ni $($ mean $=13 \pm 13 \mathrm{ppm}), \mathrm{Pb}$ (mean $=3 \pm 5 \mathrm{ppm})$. Trends in trace metal content with textural position within the analyzed crystals are weak, but cores of arsenopyrite appear to have lower $\mathrm{Au}$ concentrations than marginal zones in individual crystals.

Pyrrhotite in samples G4 and G5 contains As (up to $1696 \mathrm{ppm}$ ), Sb (up to 96 ppm), Se (up to $79 \mathrm{ppm}$ ), Ni (up to $89 \mathrm{ppm}$ ) and Co (up to $45 \mathrm{ppm}$ ). Gold contents are 
460 below limits of detection in all pyrrhotite analyses. Chalcopyrite in samples G4 and

461 G5 contains some concentrations of Ag (up to $9.8 \mathrm{ppm}$ ) and Bi (up to $66 \mathrm{ppm}$ ).

462

$463 \quad \delta^{34} S$ values of sulfides

464 The sulfur isotope data show two distinct groups. In samples G4 and G5, $\delta^{34}$ S values 465 in pyrite, pyrrhotite and chalcopyrite are comparable, 0.7- 3.7 \%o (ESM Table 6). In 466 sample G7, $\delta^{34} \mathrm{~S}$ values in pyrite range from -9.3 to $-10.6 \%$. Disseminated large 467 euhedral crystals of pyrite give $\delta^{34} \mathrm{~S}$ values of $2.1-3.7 \%$. In some individual crystals, 468 the $\delta^{34}$ S values of rims (3.3 and 3.7\%o) are consistently higher than those of the cores 469 (2.1 and $2.3 \%$ ). There is no systematic variation in the $\delta^{34} \mathrm{~S}$ value between pyrite 470 and pyrrhotite, though microscopic investigation showed replacement of pyrite471 arsenopyrite by pyrrhotite and chalcopyrite. The $\delta^{34} \mathrm{~S}$ values of isolated crystals of pyrrhotite in two samples are nearly identical $\left(2.0-2.6 \%\right.$ ). The $\delta^{34}$ S values of pyrrhotite overgrowths on pyrite and arsenopyrite in samples G4 and G5 are variable (0.7-2.9\%). Only one chalcopyrite grain is analyzed for its $\mathrm{S}$ isotope composition, which is clearly comparable to the $\delta^{34} \mathrm{~S}$ value of the adjacent pyrite $(2.4$ $\%$ ). Pyrite disseminated in carbonatized wallrock (sample G7) shows no distinct isotopic variations. The euhedral recrystallized cores were too small for ablation.

\section{Oxygen, $C$ and Sr isotopes of carbonate}

480 The oxygen isotope values are generally constant ( $\delta^{18} \mathrm{O}$ values $=10.5$ to $11.9 \%$. ESM 481 482 Table 7). One sample has exceptionally a $\delta^{18} 0$ value of $20 \%$. The $\delta^{18} 0$ values of vein carbonate are nearly constant (10.5 to $11.9 \%$ ). One sample with an exceptionally higher $\delta^{18} 0$ value $(20 \%)$ is considered unrelated to the hydrothermal assemblage. It is therefore discarded in the calculations of ore fluids. The corresponding $\delta^{18} \mathrm{OH}_{\mathrm{H}} \mathrm{O}$ values, calculated for $280^{\circ} \mathrm{C}$ and $300^{\circ} \mathrm{C}$ based on constraints from mineral assemblages (chlorite temperature; this study) and published fluid inclusion data (El-Kazzaz 1995), indicate averages of $5.1 \pm 0.7 \%$ and $4.4 \pm 0.7 \%$, respectively. The carbon isotope values range in $\delta^{13} \mathrm{C}$ value from -4.2 to $-8.8 \%$ (ESM Table 9). There is no clear correlation between $\mathrm{O}$ and $\mathrm{C}$ isotope values. Although collected from different parts of the ore zone, six samples show rather consistent $\delta^{13} \mathrm{C}$ values $(-4.2$ to $-5.5 \%$ ). Assuming carbonate precipitation at $\sim 280^{\circ} \mathrm{C}$, these six samples define a homogenous fluid $\left(\delta^{13} \mathrm{C}=-3.7 \pm 0.8 \% 0\right)$.

The bulk of 0 isotope values overlaps with data from spilitized oceanic basalts (e.g. Kerrich et al. 1987; Alt et al. 1996) and also with the estimated compositions of metamorphic and magmatic fluids (Fig. 8; e.g., Sheppard 1986). Carbon isotope values from the Um Garayat samples overlap those of C in MORB glass (Taylor 1986), but are distinct from values for marine carbonates (Ohmoto and Rye 1979).

Strontium isotope data of two samples show mostly identical ${ }^{87} \mathrm{Sr} /{ }^{86} \mathrm{Sr}$ values (0.7024 and 0.7025), which are similar to the $\mathrm{Sr}$ isotope composition of hydrothermal carbonate from other gold deposits in the South Eastern Desert province (e.g., Romite and Qurbiai deposits, see ESM Table 7). Also, these values overlap strongly with the initial ${ }^{87} \mathrm{Sr} /{ }^{86} \mathrm{Sr}$ ratio in island arc bimodal metavolcanic rocks $(\sim 710 \mathrm{Ma})$ from the Um Samiuki area in the South Eastern Desert $(\sim 0.7022$; Stern et al. 1991), and with those of the 710-700 Ma gabbroid-granitoid rocks from 
the same terrane (0.7023-0.7026; Dixon 1981). The same values are reported for

506 carbonate veins cutting sheared metavolcanic rocks and from listvenite-altered 507 serpentinites in the Central Eastern Desert (Stern and Gwinn 1990; Boskabadi et al. 508 2016). Stern and Hedge (1985) suggested that the field of initial ${ }^{87} \mathrm{Sr} /{ }^{86} \mathrm{Sr}$ for the 509 Egyptian basement represents an upper limit for the isotopic composition of $\mathrm{Sr}$ in the 510 depleted mantle beneath northeast Africa at 780-550 Ma (Fig. 8).

\section{Discussion and conclusions}

\section{Mineral paragenesis}

515 Based on the textural relationships, coarse-grained massive blocky crystals of pyrite 516 and arsenopyrite are overgrown or replaced by pyrrhotite, chalcopyrite, sphalerite, 517 galena and gersdorffite. Free-milling gold specks are associated with galena and 518 chalcopyrite in microfractures or attached to pyrite and arsenopyrite boundaries. A 519 different variety of pyrite is observed in intensely carbonatized, carbonaceous 520 metasiltstone and meta-agglomerates. This type of pyrite is characterized by 521 recrystallized cores and oscillatory margins. Based on the petrographic observations 522 this pyrite is unrelated to the hydrothermal Au-sulfide mineralization as emphasized 523 by the distinct depleted S-isotope values and different trace element composition. 524 Trace elements by LA-ICP-MS on recrystallized pyrite reveal high concentrations of $525 \mathrm{Cu}, \mathrm{Ni}, \mathrm{Co}, \mathrm{Pb}, \mathrm{Sb}$, and As. The 'hydrothermal' massive blocky pyrite in quartz veins, 526 on the other hand, contains only traces of $\mathrm{As}, \mathrm{Zn}, \mathrm{Cu}$ and $\mathrm{Pb}$. Gold in both types of 527 pyrite and in pyrrhotite is very low. Measurable concentrations of Au (up to 16.9 528 ppm, ave. $6.9 \mathrm{ppm}$ ) were only reported in arsenopyrite from quartz veins. Free529 milling gold is associated with late-paragenetic chalcopyrite, pyrrhotite, sphalerite, 530 531

532 Isotopic constraints on the sources of ore fluids

533 The $\mathrm{O}, \mathrm{C}$ and $\mathrm{Sr}$ isotopic composition of the hydrothermal carbonate from the Um 534 Garayat deposit is similar to mafic volcanic rocks which are the most abundant host 535 rock in and surrounding the mine area. These isotopic data would be consistent with 536 a number of different fluid sources; 1) metamorphic devolatilization of a dominantly 537 mafic igneous ( \pm sedimentary) lower crust, 2) mantle volatiles degassed either 538 directly from the mantle or transported through syn-orogenic magmas, and 3) 539 surficial fluids that have homogenized with the dominantly mafic host rocks. 540 Involvement of surficial fluids such as meteoric water or seawater has been indicated 541 through $\mathrm{O}$ and $\mathrm{Sr}$ isotope analyses of carbonate veins in other parts of the Eastern 542 Desert of Egypt (Boskabadi et al. 2016), where the isotope data is interpreted to 543 show mixing between deep-sourced fluids and meteoric or formation water. One of 544 the carbonate samples from the Um Garayat samples shows high ${ }^{18} 0$ values that 545 could indicate involvement of surficial fluids such as meteoric water or seawater.

Taken in isolation, the combined isotopic compositions of the Um Garayat hydrothermal carbonates (Fig. 8) cannot distinguish between the main fluid sources suggested in other orogenic gold deposits; metamorphic, magmatic and mantle fluids. The $\mathrm{O}$ and $\mathrm{C}$ isotope values of carbonate from the Um Garayat deposit are 
similar to those reported for other gold deposits in the South Eastern Desert (Table 8), suggesting regional fluid circulation. These isotopic fluid compositions are similar to those reported from many other orogenic gold terrains worldwide such as the Abitibi greenstone belt (Kerrich et al. 1987), where devolatilizing lower crustal regions of dominantly mafic igneous composition with possible contribution of $\mathrm{CO}_{2}$ from the mantle are suggested to be the most likely fluid source for hydrothermal carbonate mineralization.

The $\delta^{34}$ S values of sulfides in quartz veins in samples G4 and G5 show a narrow range (1.6 to $3.7 \%$ ) possibly reflecting a single origin. Assuming sulfide deposition at $\sim 340^{\circ} \mathrm{C}$, based on arsenopyrite geothermometry, the calculated $\delta^{34} \mathrm{~S}$ values of fluid

560 in equilibrium with the measured sulfides had $\delta^{34}$ S values $(+1.1$ to $+2.6 \%$; Ohmoto and Rye 1979). Similar to the O-C-Sr data, this value would be consistent with a number of different fluid sources including devolatilizing mafic rocks at depth, magmatic, or mantle fluids (Ohmoto 1986). Sample G7, which contains carbonaceous 564 lamellae shows strongly depleted $\delta^{34}$ S values (-9 to $-10 \% 0$ ) which may indicate localized remobilization of bacterially mediated diagenetic sulfide from a 566 carbonaceous material bearing metasedimentary host rock. The variation of $\delta^{34} S$ 567 values shows some similarities to that reported for the El Sid deposit (Zoheir and Moritz 2014) where $\delta^{34}$ S values range from +5.5 to $-12 \%$. In the El Sid deposit, early pyrite has more positive $\delta^{34} \mathrm{~S}$ values, while the late, lower temperature sulfides including sphalerite, galena and chalcopyrite have more negative values. These data are interpreted to indicate interaction between late paragenetic ore fluids with carbonaceous host rocks (Zoheir and Moritz 2014). Interaction between carbonaceous host rocks and ore fluids is also reported at other deposits such as Barramiya through generation of $\mathrm{CH}_{4}$-rich fluid inclusions (Zoheir and Lehmann 2011).

Comparison with other gold deposits in the South Eastern Desert - a regional ore fluid

The relatively few investigations of the nature and evolution of gold-bearing fluids and physicochemical conditions of gold deposition along the western Wadi Allaqi district indicate a fluid of consistent composition and similar conditions of gold deposition. For the Atshani, Nagib and Um Garayat deposits, El-Kazzaz (1995) described groups of fluid inclusions with highly variable molar $\mathrm{CO}_{2}: \mathrm{H}_{2} \mathrm{O}$ ratios. He suggested that unmixing of an originally aqueous-carbonic fluid by pressure decrease in the vein system led to gold deposition. The estimated entrapment conditions were $2 \mathrm{kbar}$ and $320-280^{\circ} \mathrm{C}$. This study reported data from one goldbearing quartz vein sample from the Um Garayat mine, with $\delta^{18} 0$ and $\delta D$ values of 12.9 and $-89 \%$, respectively (El-Kazzaz 1995), which are within the range of the 0 isotope data reported in this study. Although fluid inclusion and stable isotope data did not provide a definitive identification of the source of ore fluid, a shear-related metamorphic fluid was suggested based on the internal texture of quartz veins and regional setting of the mineralized shear zones (El-Kazzaz 1995). Similar fluid compositions (<8wt\% $\mathrm{NaCl}$ eq.) and of fluid entrapment conditions $336-287^{\circ} \mathrm{C}$ and 1.7-2.1 kbar were reported from the Um El Tuyor deposit that is located along the Allaqi-Heiani belt east of Um Garayat (Zoheir 2008a). 
In the central Allaqi-Heiani belt, gold was deposited from low salinity aqueouscarbonic ore fluids (3-8 wt\% $\mathrm{NaCl}$ eq.) under conditions of $297-323^{\circ} \mathrm{C}$ and $2-2.6$ kbar in the Betam gold deposit (Zoheir 2008b). The $\delta^{18} 0$ values of sericite-pyrite altered ore samples from the Betam deposit range from 9.6 to $11.2 \%$, lower than the composition of pelitic metasedimentary rocks, 16.6 to $18.4 \%$ (Zoheir and Qaoud 2008) but similar to the compositions reported here for the Um Garayat deposit.

These studies indicate a regional ore fluid of similar composition and precipitation of gold bearing veins under common physicochemical conditions. The window of gold mineralization occurs at temperatures and pressures of $280-340^{\circ} \mathrm{C}$ and 1.7 to $2.6 \mathrm{kbar}$, respectively. The fluid composition is of low salinity ( $<8 \mathrm{wt} \%$ $\mathrm{NaCl}$ eq.) with a $\delta^{18} \mathrm{O}$ value of between 10 and $13 \%$, irrespective of host rock composition. Sulfur isotope compositions of sulfide show a larger range indicating remobilization of local host rock sulfides at some deposits. A regionally consistent ore fluid indicates a regionally pervasive process for generation of metal rich mineralizing fluids such as prograde metamorphism.

\section{1}

\section{Genetic model and key criteria for exploration in the area}

612 In the Wadi Allaqi district, the volcano-sedimentary sequence and ophiolites (Fig. 2) 613 were generally metamorphosed under greenschist facies conditions, but peak 614 metamorphic conditions were considerably higher at depth up to $500-560^{\circ} \mathrm{C}$ and 5.5 615 6.3 kbar (Abd El-Naby and Frisch 2002). The peak metamorphism occurred coeval with the compressive deformation, manifested by regional folding and sinistral shearing (Zoheir and Klemm 2007). The estimated age of metamorphism is 600-585 $\mathrm{Ma}$, comparable with granite magmatism in the area (Abd El-Naby and Frisch 2002). Hydrated and carbonated metabasic rocks at depth could have devolatilized when metamorphic conditions crossed the greenschist-amphibolite facies boundary. This process may have resulted in the liberation of low salinity aqueous-carbonic fluid with reduced sulfur and complexed Au (e.g. Phillips 1993; Phillips and Powell 2010). This auriferous fluid could have mixed with other fluid types, especially hot magmatic fluids at depth. The overlap of metamorphism with granite magmatism in the area may imply possible contributions from magmatic fluids. This may explain the $\mathrm{S}$ isotope composition of hydrothermal vein sulfides that is very dissimilar from pyrite in the host rocks. In the Um Garayat mine area, Au-bearing fluids likely migrated upward into the crust via D3 shear zones to a crustal level of about 6-8 km (Zoheir 2008b; Emam and Zoheir 2013). The geometry of the intersecting shear zones and lithological contacts allowed physical and geochemical preference for the gold-bearing fluids to deposit economic mineralization in some areas (e.g., Um Garayat, Marahiq and Nile Valley Block).

The isotopic compositions of hydrothermal carbonate from the Um Garayat deposit largely overlap the range from orogenic gold deposits in metamorphic belts (e.g., Ridley 1997). The calculated isotopic compositions of model fluid $\left(\delta^{13} \mathrm{C}_{\mathrm{CO} 2}=-2.9\right.$ to $-7.8 \%$, and $\delta^{18} \mathrm{O}_{\mathrm{H} 2 \mathrm{O}}=+3.7$ to $+5.8 \%$ ) and geological consideration of an orogenic environment for the $\mathrm{Um}$ Garayat $\mathrm{Au}$ mineralization are consistent with a metamorphic fluid (e.g. Groves et al. 1988; Pitcairn et al. 2006). The slight variation in $\delta^{13} \mathrm{C}$ Co2 can be explained as a result of fluctuation of $\mathrm{pH}$ conditions due to loss of $\mathrm{H}_{2} \mathrm{~S}$ in the fluid by sulfide precipitation (sensu Ohmoto and Rye 1979). In addition, 
641 redox agents in carbonaceous laminae and sulfide-bearing metavolcanic642 volcaniclastic rocks led to the breakdown of gold-thiosulfide complex in the 643 mineralizing fluids and promoted gold deposition. Zones showing criteria of 644 hydrothermal alteration along shear zones cutting the island arc 645 metavolcanic/metavolcaniclastic rocks in the Wadi Allaqi district may, therefore, be 646 considered high-priority targets for drilling programs. Enhanced vectoring of 647 potential zones would build on spectral and mineralogical features indicative of fluid 648 focusing at structural intersections.

649

650

651

652

653 Basem Zoheir likes to acknowledge the Alexander von Humboldt Foundation for 654 making this work possible. Iain Pitcairn acknowledges the receipt of a Swedish 655 Research Links grant (2014-4290). The editorial work by Prof. B. Lehmann is highly 656 appreciated. Thanks are also due to Profs. A. Hassan, D. Craw and M. Steele-MacInnis 657 for their constructive suggestions and insightful comments. 


\section{References}

659

660

661

662

663

664

665

666

667

668

669

670

671

672

673

674

675

676

677

678

679

680

681

682

683

684

685

686

687

688

689

690

691

692

693

694

695

696

697

698

699

700

701

702

703

Abd El-Naby HH, Frisch W (2002) Origin of the Wadi Haimur-Abu Swayel gneiss belt, south Eastern Desert, Egypt: Petrological and geochronological constraints. Precambrian Research 113: 307-322

Abd El-Naby HH, Frisch W, Hegner E (2000) Evolution of the Pan-African Wadi Haimur metamorphic sole, Eastern Desert, Egypt. Journal of Metamorphic Petrology 18: 639-651

Abdeen MM, Abdelghaffar AA (2011) Syn- and post-accretionary structures in the Neoproterozoic central Allaqi-Heiani suture zone, Southeastern Egypt. Precambrian Research 185: 95-108

Abdelsalam MG, Abdeen MM, Dowidar HM, Stern RJ, Abdelghaffar AA (2003) Structural evolution of the Neoproterozoic western Allaqi-Heiani suture zone, Southern Egypt. Precambrian Research 124: 87-104

Abdelsalam MG, Stern RJ (1996) Sutures and shear zones in the Arabian-Nubian Shield. Journal of African Earth Sciences 23 (3): 289-310

Ali KA, Azer MK, Gahlan HA, Wilde SA, Samuel MD, Stern RJ (2010) Age constraints on the formation and emplacement of Neoproterozoic ophiolites along the AllaqiHeiani Suture, South Eastern Desert of Egypt. Gondwana Research 18: 583-595

Alt JC, Teagle DAH, Bach W, Halliday AN, Erzinger J (1996) Stable and strontium isotopic profiles through hydrothermally altered upper oceanic crust, Hole 504B. In: Alt JC, Kinoshita H, Stokking LB, Michael PJ (Eds.), Proceedings of Ocean Drilling Program, Scientific Results, College Station, TX 148: 57-69

Boskabadi A, Pitcairn IK, Broman C, Boyce A, Teagle DAH, Cooper MJ, Azer MK, Stern RJ, Mohamed FM, Majka J (2016) Carbonate alteration of ophiolitic rocks in the Arabian-Nubian Shield of Egypt: source and compositions of the carbonating fluid and implications for the formation of Au deposits: International Geology Review 59(4): 391-419

Brand WA, Coplen TB, Vogl J, Rosner M, Prohaska T (2014) Assessment of international reference materials for isotope-ratio analysis (IUPAC technical report). Pure Applied Chemistry 86: 425-467

Deines P (1989) Stable isotope variations in carbonatites. In: Bell, K. (ed) Carbonatites: genesis and evolution. Unwin Hyman, London, 301-359

Dixon TH (1981) Age and chemical characteristics of some pre-Pan-African rocks in the Egyptian Shield. - Precambrian Research 14: 119-133

El-Kazzaz YAHA (1995) Tectonics and mineralization of Wadi Allaqi, south Eastern Desert, Egypt. PhD thesis, University of Luton 220p

El-Makky AM (2000) Applications of geostatistical methods and zonality of primary haloes in geochemical prospecting at the Um Garayat gold mine area, south Eastern Desert, Egypt. Delta Journal of Science 24(1): 159-192

El-Makky AM (2011) Statistical analyses of La, Ce, Nd, Y, Nb, Ti, P, and Zr in bedrocks and their significance in geochemical exploration at the Um Garayat gold mine area, Eastern Desert, Egypt. Natural Resources Research 20(3): 157-176

El-Nisr SA (1997) Late Precambrian volcanism in Wadi El Allaqi area, South Eastern Desert, Egypt: An evidence for transitional continental arc/margin environment. Journal of African Earth Sciences 24(3): 301-313 
El Ramly MF, Ivaanov SS, Kochin GC (1970) The occurrence of gold in the Eastern Desert of Egypt. Studies on Some Mineral Survey of Egypt 21, 1-22

El-Shazly EM, Hashad AH, Sayyah TA, Bassyuni FA (1973) Geochronology of Abu Swayel area, South Eastern Desert. Egyptian Journal of Geology 17: 1-18

El-Shimi KA (1996) Geology, structure and exploration of gold mineralization in Wadi Allaqi area (SW, Eastern Desert, Egypt). Ph.D. Thesis, Ain Shams University $326 p$

Emam A, Qaoud N, Abdel Rahman E, Fawzy KM (2014) Comprehensive mapping of the island arc rocks in the Marahiq area, South Eastern Desert, Egypt. The Open Geology Journal 8: 84-96

Emam A, Zoheir B (2013) $\mathrm{Au}$ and $\mathrm{Cr}$ mobilization through metasomatism: microchemical evidence from ore-bearing listvenite, South Eastern Desert of Egypt. Journal of Geochemical Exploration 125: 34-45

Finger E, Helmy HM (1998) Composition and total-Pb model ages of monazite from high-grade paragneisses in the Abu Swayel area, southern Eastern Desert, Egypt. Mineralogy and Petrology 62: 269-289

Garde-Schönberg D, Muller S (2014) Nano-particulate pressed powder tablets for LAICP-MS. Journal of Analytical Atomic Spectrometry 29: 990-1000

Gilbert SE, Danyushevsky LV, Rodermann T, Shimizu A, Gurenko A, Meffre S, Thomas $\mathrm{H}$, Large RR, Death D (2014) Optimisation of laser parameters for the analysis of sulfur isotopes in sulfide minerals by laser ablation ICP-MS. JAAS 29: 1042-1051

Groves DI, Phillips GN, Ho SE, Houstoun SM, Standing CA (1988) Craton-scale distribution of greenstone gold deposits: Predictive capacity of the metamorphic model. Economic Geology 83: 2045-2058

Hassan MA, Hashad AH (1990) Precambrian of Egypt. In: Said R (Ed.) The Geology of Egypt. Balkama, Rotterdam, Netherlands 201-245

Hussein AA (1990) Mineral deposits of Egypt. In: Said R (Ed.) The geology of Egypt. . Balkama, Rotterdam, Netherlands 511-566

Ivanov TG (1988) Report of study of hydrothermal alterations in localities Um Garayat and Um Tundup, South Eastern Desert, Egypt. United Nations Development Programme in the Arab Republic of Egypt. Internal Report, Geological Survey of Egypt

Ivanov TG, Hussein AA (1972) Assessment of the mineral potential of the Aswan region. Technical. Report on the geological operations carried out from July 1968 to June 1972. Egyptian Geological Survey, Internal report, No. 68/73

Kerrich R, Fryer BJ, King RW, Willmore LM, van Hees E (1987) Crustal outgassing and LILE enrichment in major lithosphere structures, Archean Abitibi greenstone belt: evidence on the source reservoir from strontium and carbon isotope tracers. Contributions to Mineralogy and Petrology 97: 156-168

Khalil AE, Obeid MA, Azer M (2014) Serpentinized Peridotites at the North Part of the Wadi Allaqi District (Egypt): Implications for the Tectono-Magmatic Evolution of Fore-arc Crust. Acta Geologica Sinica 88(5): 421-1436

Klemm DD, Klemm R, Murr A (2001) Gold of the Pharaohs-6000 years of gold mining in Egypt and Nubia. Journal of African Earth Sciences 33: 643-659 
765

766

767

768

769

770

771

772

773

774

775

776

777

778

779

780

781

782

783

784

785

786

787

788

789

790

791

792

793

794

795

Klemm R, Klemm D (2013) Gold and Gold Mining in Ancient Egypt and Nubia, Geoarchaeology of the Ancient Gold Mining Sites in the Egyptian and Sudanese Eastern Deserts. Springer-Verlag, Berlin, Heidelberg, 663p

Kranidiotis P, MacLean WH (1987) Systematics of chlorite alteration at the Phelps Dodge massive sulphide deposit, Matagami,Quebec. Economic Geology 82: 18981911

Kretschmar U, Scott SD (1976) Phase relations involving arsenopyrite in the system Fe-As-S and their application. Canadian Mineralogist 14: 364-386

Kusky TM, Ramadan TM (2002) Structural controls on Neoproterozoic mineralization in the South Eastern Desert, Egypt: an integrated field, Landsat TM and SIR-C/X SAR approach. Journal of African Earth Sciences 35: 107-121

Kyser TK (1986) Stable isotope variations in the mantle. In: Valley, J. W. (Ed.) Stable Isotopes in High Temperature Geological Processes. Mineralogical Society of America, Reviews in Mineralogy 16: 141-164

Lanari P, Olivier Vidal O, De Andrade V, Dubacq B, Lewin E, Grosch EG, Schwartz S (2014) XMapTools: A MATLAB (C)-based program for electron microprobe X-ray image processing and geothermobarometry. Computers and Geosciences 62: 227-240

Müller W, Shelley M, Miller P, Broude S (2009) Initial performance metrics of a new custom-designed ArF excimer LA-ICPMS system coupled to a two-volume laserablation cell. Journal of Analytical Atomic Spectrometry 24: 209-214

Noweir AM, El-Amawy MA, Rashwan AA, Abdel-Aziz AM (1996) Geology and structural evolution of the Pan-African basement rocks around Wadi Umm Araka, Northeast Wadi Allaqi, South Eastern Desert, Egypt. Egyptian Journal of Geology 40(2): 477-512

Ohmoto H (1986) Stable isotope geochemistry of ore deposits. In: Valley JW, Taylor JrHP, O’Neil JR (Eds.) Stable Isotopes in High Temperature Geological Processes. Review in Mineralogy 16: 491-559

Ohmoto H, Rye RO (1979) Isotopes of sulfur and carbon. In: Geochemistry of Hydrothermal Ore Deposits. In: Barnes HL (Ed.). J Wiley and Sons 509-567

Osman AMA (2014) An integrated metallotect and petrographic model for gold mineralization in the Eastern Desert of Egypt; a new prospecting vision. Egyptian Journal of Pure and Applied Science 52(2): 41-54

Oweiss KA, Khalid AM (1991) Geochemical prospecting at Um Qareiyat gold deposits, South Eastern Desert, Egypt. Annals Geological Survey of Egypt 17: 145-151

Phillips GN (1993) Metamorphic fluids and gold. Mineralogical Magazine 57: 365-374

Phillips GN, Powell R (2010) Formation of gold deposits: A metamorphic devolatilization model: Journal of Metamorphic Geology 28: 689718

Pitcairn IK, Teagle DAH, Craw D, Olivo GR, Kerrich R, Brewer TS (2006) Sources of metals and fluids in orogenic gold deposits: insights from the Otago and Alpine Schists, New Zealand. Econ Geol 101:1525-1546

Ramadan TM, Sadek MF, Abu El Leil I, Salem SM (2005) Um El Touyur El Fuqani gold mineralization, South Eastern Desert, Egypt: using Landsat ETM+ imagery. Annals of the Geological Survey of Egypt 28: 263-281 
Ramadan TM, Sultan SA (2003) Integration of geological, remote sensing and geophysical data for the identification of massive sulphide zones at Wadi Allaqi area, South Eastern Desert, Egypt. Geoscience and Remote Sensing Symposium, Proceedings IEEE International 2589-2591

Ramadan TM, Abdelsalam MG, Stern RJ (2001) Mapping gold -bearing massive sulphide deposits with Landsat TM and SIR - C/X SAR imagery in the Neoprtoterozoic Allaqi Suture, SE Egypt. Journal of Photogrammetric Engineering and Remote Sensing 67(4): 491-498

Ray JS, Ramesha R, Pandea K, Trivedi JR, Shukla PN, Patel PP (2000) Isotope and rare earth element chemistry of carbonatite \pm alkaline complexes of Deccan volcanic province: implications to magmatic and alteration processes [J]. Journal of Asian Earth Sciences 18: 177-194

Ridley J (1997) Syn-metamorphic gold deposits in amphibolite and granulite facies rocks. Mitt. österreichen Miner. Ges. 142: 101-110

Rosenbaum J, Sheppard SMF (1986) An isotopic study of siderites, dolomites and ankerites at high temperatures. Geochimica et Cosmochimica Acta 50: 1147-1150

Sabet AH, Khalifa KA, Khalid AM, Arnous MM, Hassan SM, Abdel Daim AM (1983) Results of prospecting-exploration, work carried out at Um Qareiyat gold-ore deposits, Southeastern Desert, Egypt. Internal Report, Geological Survey of Egypt

Sheppard SMF (1986) Characterization and isotopic variations in natural waters. In: Valley JW, Taylor HP Jr, O'Neil JR (Eds.) Stable Isotopes in High Temperature Geological Processes. Mineralogical Society of America, Reviews in Mineralogy 16: $165-183$

Stern RJ, Gwinn CJ (1990) Origin of late Precambrian intrusive carbonates, Eastern Desert of Egypt and Sudan: C, $\mathrm{O}$ and Sr isotopic evidence: Precambrian Research 46: $259-272$

Stern RJ, Hedge CE (1985) Geochronologic and isotopic constraints on Late Precambrian crustal evolution in the Eastern Desert of Egypt: American Journal of Science 285: 97-127

Stern RJ, Kröner A, Rashwan AA (1991) A late Precambrian ( 710 Ma) high volcanicity rift in the south Eastern Desert of Egypt: Geologische Rundschau 80: 155-170

Taylor HP, Frechen J, Degens ET (1967) Oxygen and carbon isotope studies of carbonatites from the Laacher See District, West Germany and the Alnö District, Sweden. Geochimica et Cosmochimica Acta 31, 407-430

Taylor BE (1986) Magmatic volatiles: isotopic variations of C, H, and S. In: Valley JW, Taylor HP Jr, O'Neil Jr (Eds.) Stable isotopes in high temperature geological processes. Mineral Society of America 16:185-226

Van Achterbergh ERCG, Jackson SE, L GW (2001) Data reduction software for LA-ICPMS p. 239-243, in: S. P.), (Ed.), Laser-Ablation-ICPMS in the Earth Sciences Principles and applications, Mineralogical Association of Canada short course series St John, Newfoundland

Verkouteren RM, Klinedinst DB (2004) Value assignment and uncertainty estimation of selected light stable isotope reference materials: RMs 8543-8545, RMs 85628564, and RM 8566. NIST Special publication 260-149, 58p 
841

842

843

844

845

846

847

848

849

850

851

852

853

854

855

856

857

858

859

860

861

862

863

864

865

866

867

868

869

870

871

872

873

874

875

Wilson SA, Ridley WI, Koenig AE (2002) Development of sulfide calibration standards for the laser ablation inductively-coupled plasma mass spectrometry technique. Journal of Analytical Atomic Spectrometry 17: 406-409

Yuan JH, Zhan XC, Fan CZ, Zhao LH, Sun DY, Jia ZR, Hu MY, Kuai LJ (2012) Quantitative Analysis of Sulfide Minerals by Laser Ablation-Inductively Coupled Plasma-Mass Spectrometry Using Glass Reference Materials with Matrix Normalization Plus Sulfur Internal Standardization Calibration. Chinese Journal of Analytical Chemistry 40: 201-207

Zheng YF, Hoefs J (1993) Carbon and oxygen isotope covariations in hydrothermal calcites: theoretical modeling on mixing processes and application to Kushikino gold mining area in Japan. Mineralium Deposita 25: 246 -250

Zoheir BA (2004) Gold mineralization in the Um El Tuyor area, south Eastern Desert, Egypt: geologic context, characteristics and genesis. Ph.D. Thesis, Ludwig Maximilians Universität, München, Germany 159p

Zoheir BA (2008a) Characteristics and genesis of shear zone-related gold mineralization in Egypt: A case study from the Um El Tuyor mine, south Eastern Desert. Ore Geology Reviews 34: 445-470

Zoheir BA (2008b) Structural controls, temperature-pressure conditions and fluid evolution of orogenic gold mineralisation in Egypt: a case study from the Betam gold mine, south Eastern Desert. Mineralium Deposita 43: 79-95

Zoheir BA (2012) Controls on lode gold mineralization, Romite deposit, South Eastern Desert, Egypt. Geoscience Frontiers 3 (5): 571-585

Zoheir BA, Emam A (2014) Field and ASTER imagery data for the setting of gold mineralization in Western Allaqi-Heiani belt, Egypt: A case study from the Haimur deposit. African Earth Science 99 (1): 150-164

Zoheir BA, Klemm DD (2007) The tectono-metamorphic evolution of the central part of the Neoproterozoic Allaqi-Heiani suture, south Eastern Desert of Egypt. Gondwana Research 12: 289-304

Zoheir BA, Lehmann B (2011) Listvenite-lode association at the Barramiya gold mine, Eastern Desert, Egypt. Ore Geology Reviews 39(1): 101-115

Zoheir BA, Moritz R (2014) Fluid evolution in the El-Sid gold deposit, Eastern Desert, Egypt. Geological Society, London, Special Publications, 402(1): 147-175

Zoheir BA, Qaoud NN (2008) Hydrothermal alteration geochemistry of the Betam gold deposit, south Eastern Desert, Egypt: mass-volume-mineralogical changes and stable isotope systematics. Applied Earth Science 117(2): 55-76 


\section{Figure captions}

Fig. 1. Simplified structural map of south Egypt and north Sudan. The Allaqi-Heiani suture and Hamisana Zone separate the South Eastern Desert, Gabgaba and Gerf terranes (modified from Ramadan et al. 2001; Abdelsalam et al. 2003).

Fig. 2. Geological map of the Western Allaqi district. Location of gold occurrences are given in numbers and names in the legend. Inset showing the location of the map is on Egypt outline map.

Fig. 3. Geological map of the Um Garayat gold mine. Also shown are sample locations and numbers.

Fig. 4. Reflected light photomicrographs showing the mineralogy and textural relationships in the Um Garayat Au deposit. (a) euhedral pyrite (py) crystal shows zoning and recrystallized core (sample G7), (b) recrystallized parts in colloform pyrite (sample G22), (c) intergrown pyrite and arsenopyrite (apy) replaced by pyrrhotite (po), (d) galena (gn) and chalcopyrite (cpy) heal spaces between euhedral pyrite and arsenopyrite (sample G4), (e) intergrown pyrrhotite and chalcopyrite replace pyrite and arsenopyrite (sample G5), (f) small euhedral arsenopyrite crystals enclosed in intergrown pyrrhotite and chalcopyrite (sample G4), (g) pyrrhotite replaces arsenopyrite in sample G4, (h) blocky anhedral pyrite partially replaced by chalcopyrite and gersdorffite (grsd), (i) gold ( $\mathrm{Au}$ ) inclusions along microfractures in pyrite and chalcopyrite replaces pyrite in peripheral parts.

Fig. 5. Back-scattered electron images showing the mode of occurrence of gold specks in the Um Garayat deposit. (a) gold ( $\mathrm{Au}$ ) and chalcopyrite (cpy) healing aggregated arsenopyrte (apy) crystals. Notice the euhedral pyrite (py) crystals at direct contact with arsenopyrite. The latter is replaced by pyrhotite (po) and chalcopyrite, (b) euhedral arsenopyrite crystal partially replaced and overgrown with pyrrhotite and chalcopyrite and intergrown with pyrite. Gold blebs at contacts between pyrite and arsenopyrite and commonly intergrown with chalcopyrite, (c) gold and chalcopyrite healing microfractures in a large pyrite crystal, (d) gold, chalcopyrite and gersdorffite (grsd) along microfractures in anhedral pyrite.

Fig. 6. Paragenetic sequence of the Um Garayat gold deposit in relation to the deformation history of the Wadi Allaqi district.

Fig. 7. Back-scattered electron images showing the hydrothermal minerals in mineralized quartz veins in addition to quartz. (a) disseminated arsenopyrite (apy) embedded in dolomite (dol) intergrown with chlorite (chl) and sericite (ser). Notice that calcite (cal) is uncommon in quartz veins, (b) disseminatins of pyrite and arsenopyrite in quartz intermingled with chlorite and dolomite. Late veinlets of acicular goethite (gt) cut the chlorite domains.

Fig. 8. Plots of $\mathrm{O}, \mathrm{C}$ and $\mathrm{Sr}$ isotope data for carbonates from the Um Garayat gold deposit. (a) $\delta^{13} \mathrm{C} v s . \delta^{18} \mathrm{O}$, (b) $\delta^{13} \mathrm{C} v s .{ }^{87} \mathrm{Sr} /{ }^{86} \mathrm{Sr}$ at $\sim 600 \mathrm{Ma}$. Fields and references displayed are: $\mathbf{M R}=$ mantle/magmatic rocks (Zheng and Hoefs 1993), OB = oceanic basalt (Kyser 1986), DM= Depleted mantle, intrusive carbonatite field (Taylor et al. 1967; Deines 1989), IGC 
925 = igneous calcite (Ray et al. 2000), RQC = Au-quartz carbonate veins from the Romite 926 deposit (Zoheir 2012). The isotopic compositional range of three gold deposits in the 927 South Eastern Desert is the broken line ellipsoid. $\mathbf{M F}=$ modelled fluid calculated for the 928 six least variable samples of Um Garayat at $\mathrm{T}=280^{\circ} \mathrm{C}$. Data of carbonate from the Qurbiai 929 and Romite gold deposits are plotted for comparison with data of the Um Garayat 930 deposit. 


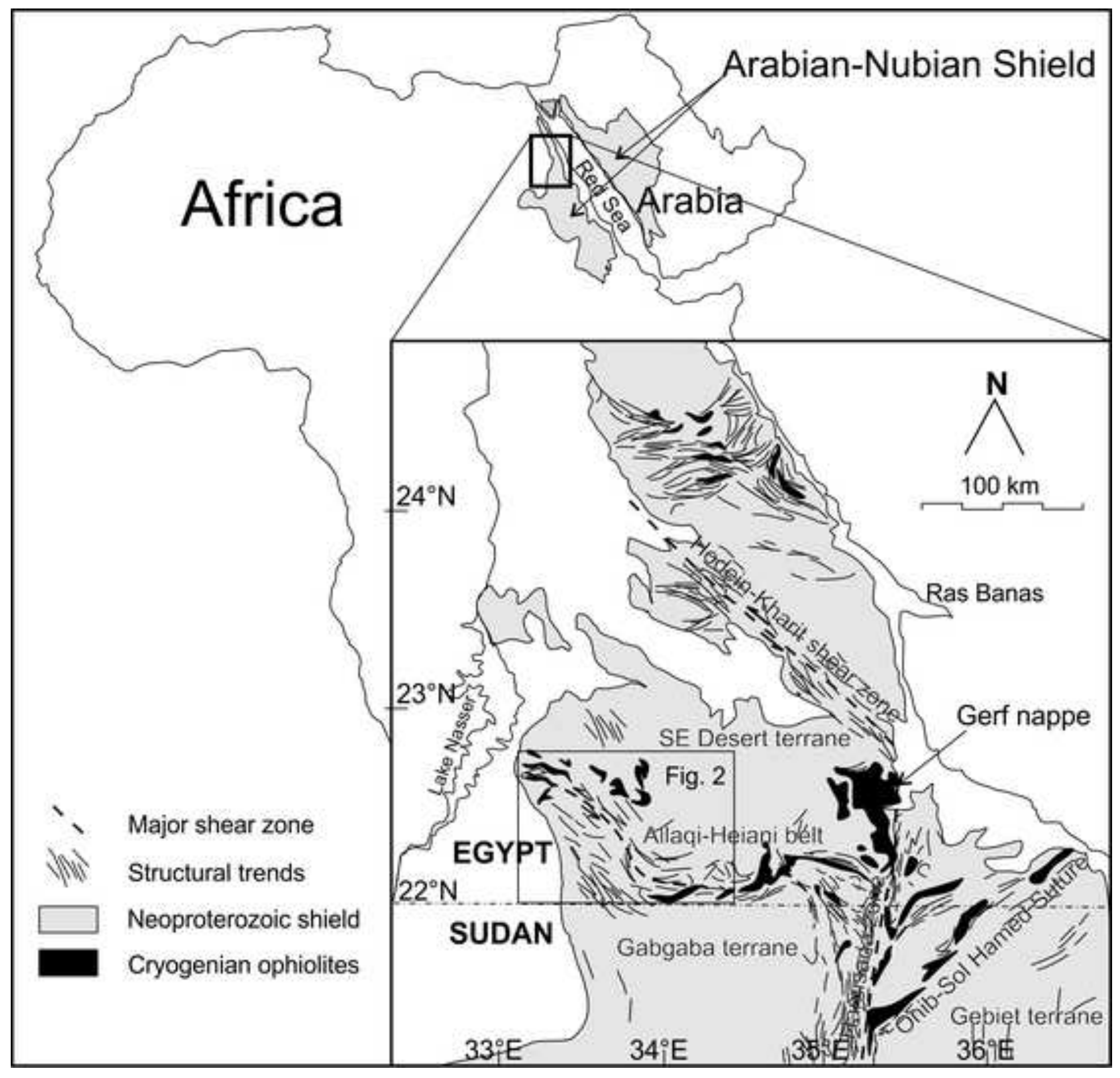



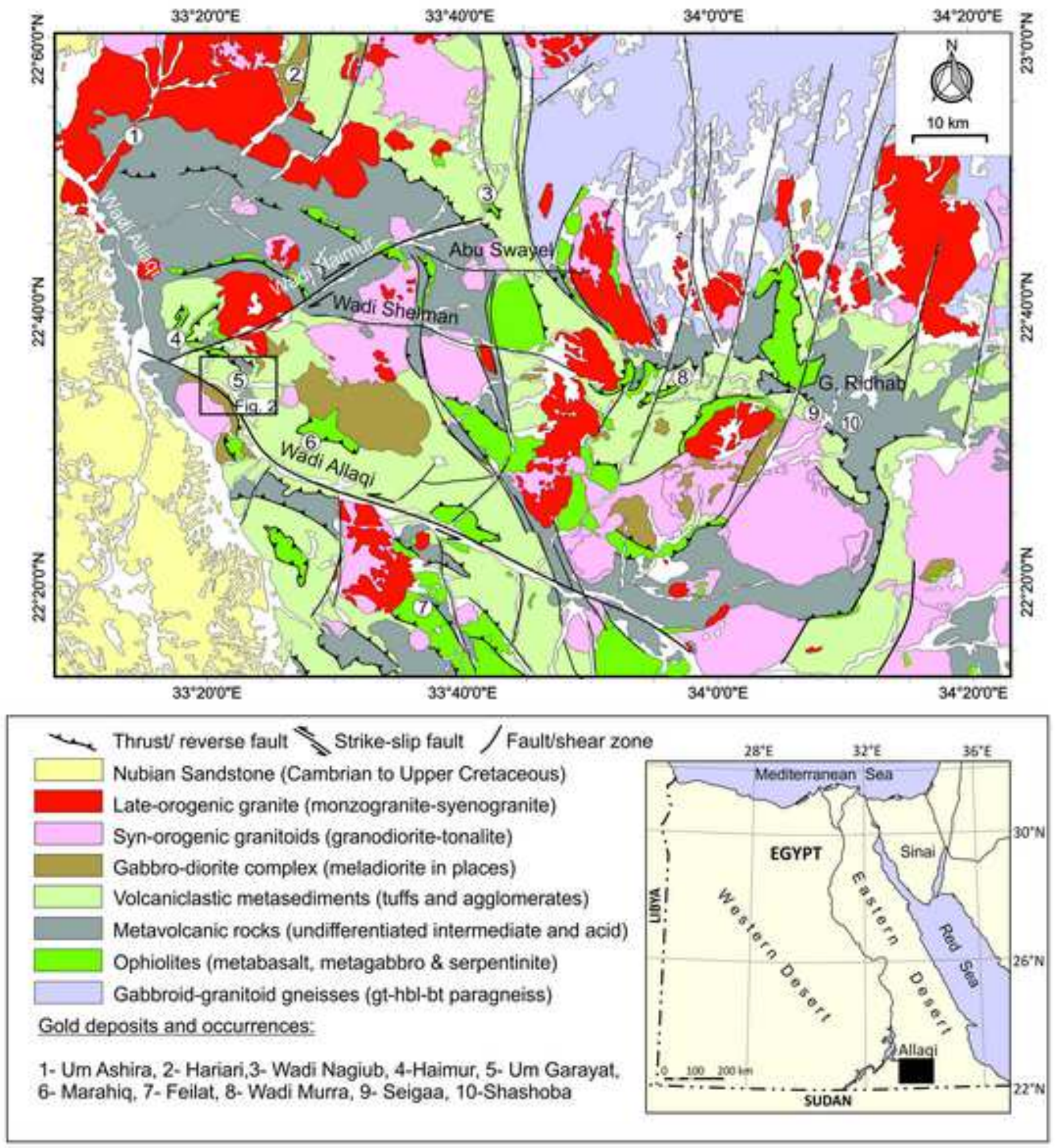


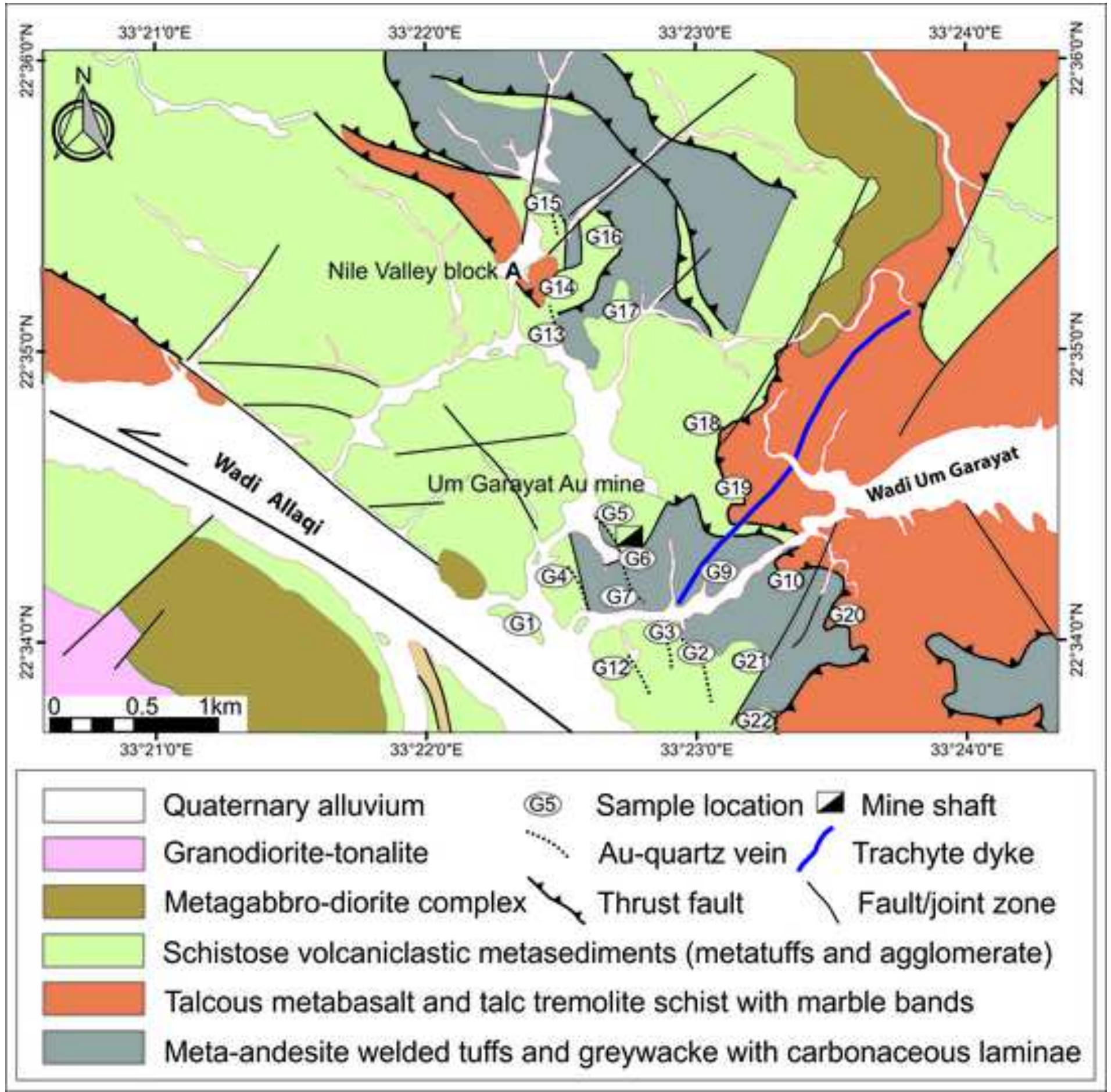




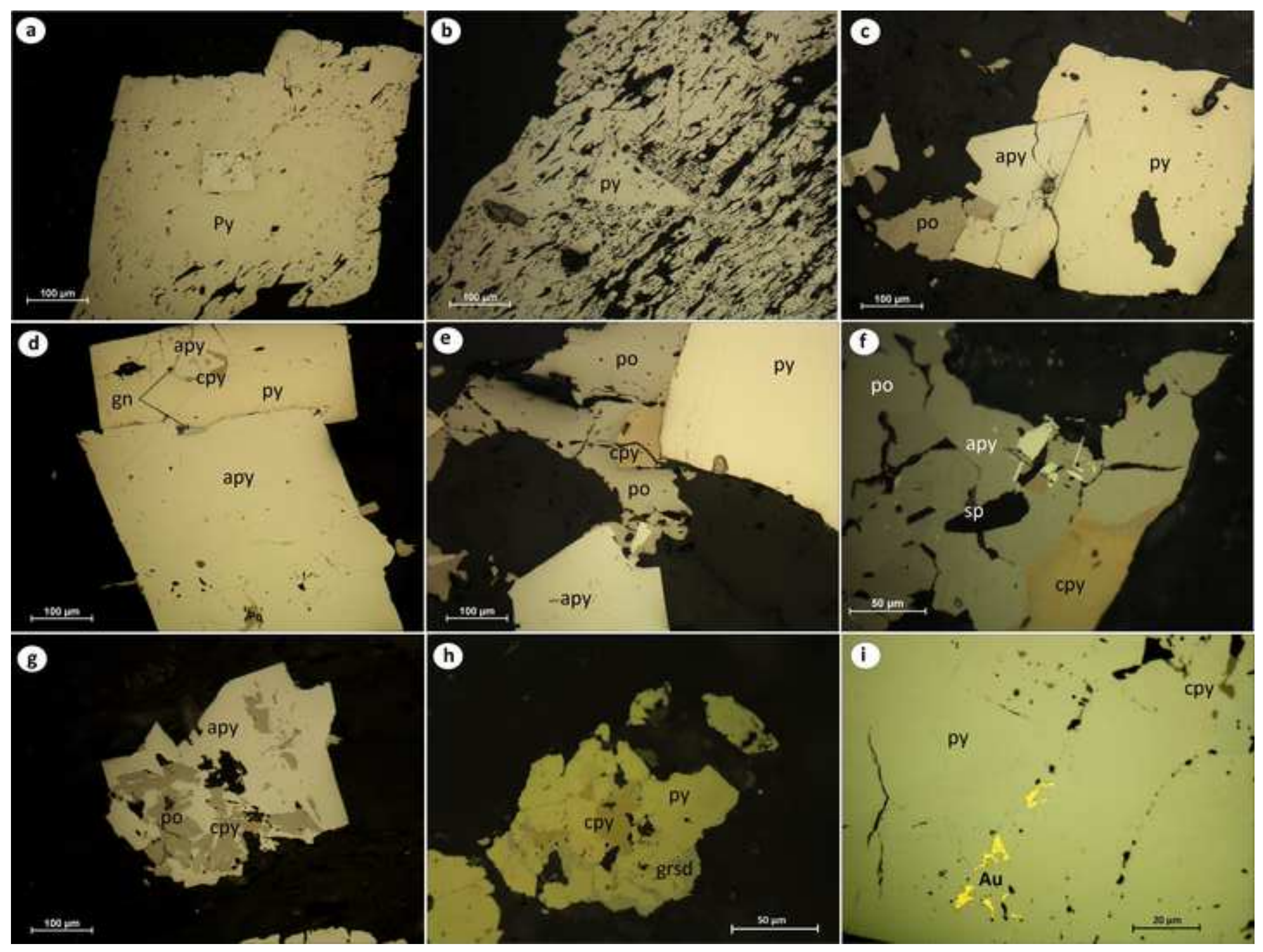




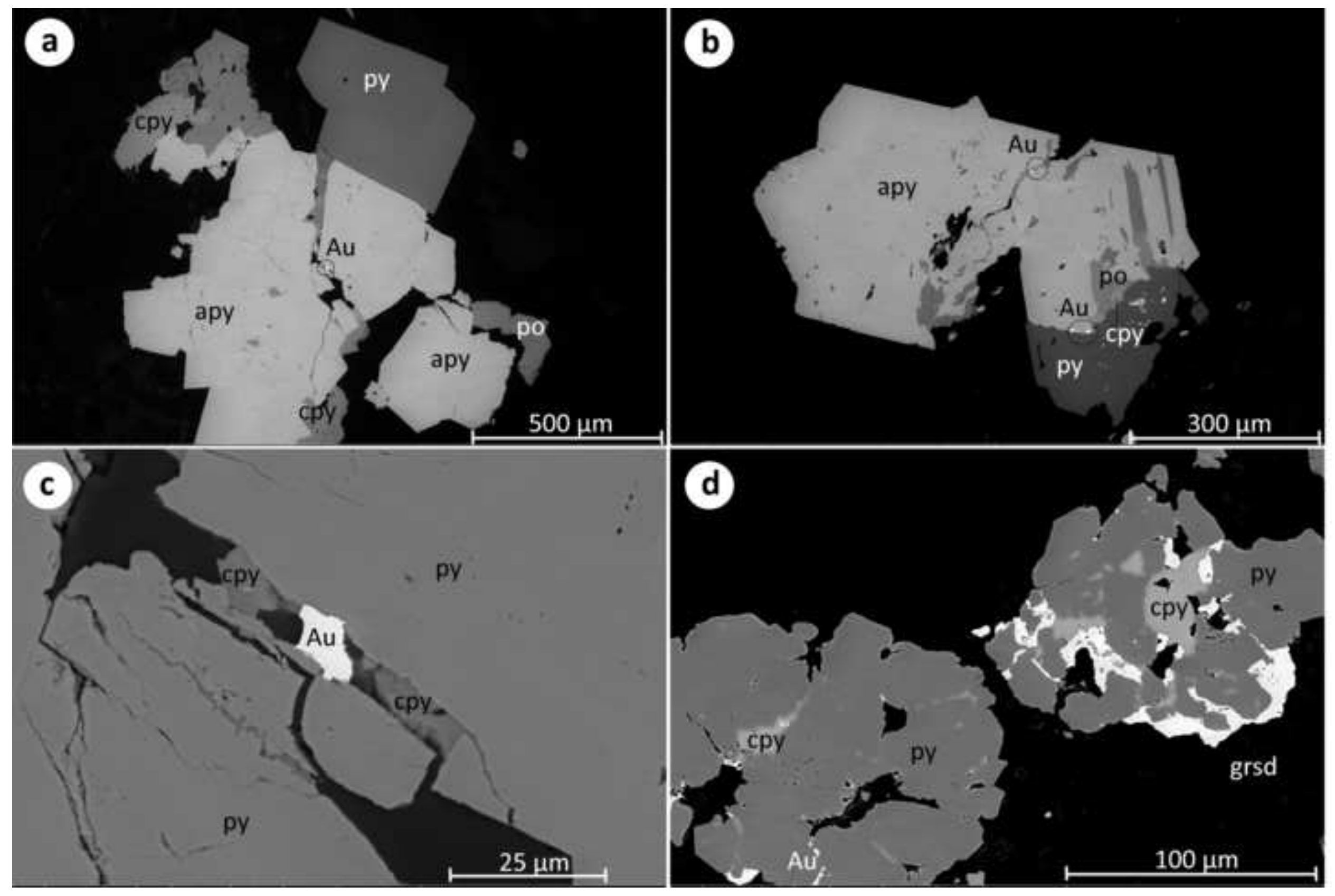




\begin{tabular}{|c|c|c|}
\hline & Pre-ore stage & Hydrothermal ore stage \\
\hline & & Early \\
\hline Recrystallized pyrite & $m m m m m$ & \\
\hline Blocky pyrite & & $(m) m m m) m m m)$ \\
\hline Arsenopyrite & & $m m m m m m m m m)$ \\
\hline Pyrrhotite & & $m m m$ \\
\hline Chalcopyrite & & $m m m m$, \\
\hline Sphalerite & & $m m m$ \\
\hline Galena & & $m m$ \\
\hline Gersdorffite & & $m m m m$ \\
\hline Free gold & & $m m$ \\
\hline Mineral assemblage & chlorite-dolomite \pm graphite & quartz-sericite-chlorite-rutile-calcite \\
\hline Deformation stage & D2: NE-SW transpression & D3: NNW-trending folding and shearing \\
\hline
\end{tabular}

Hydrothermal ore stage 


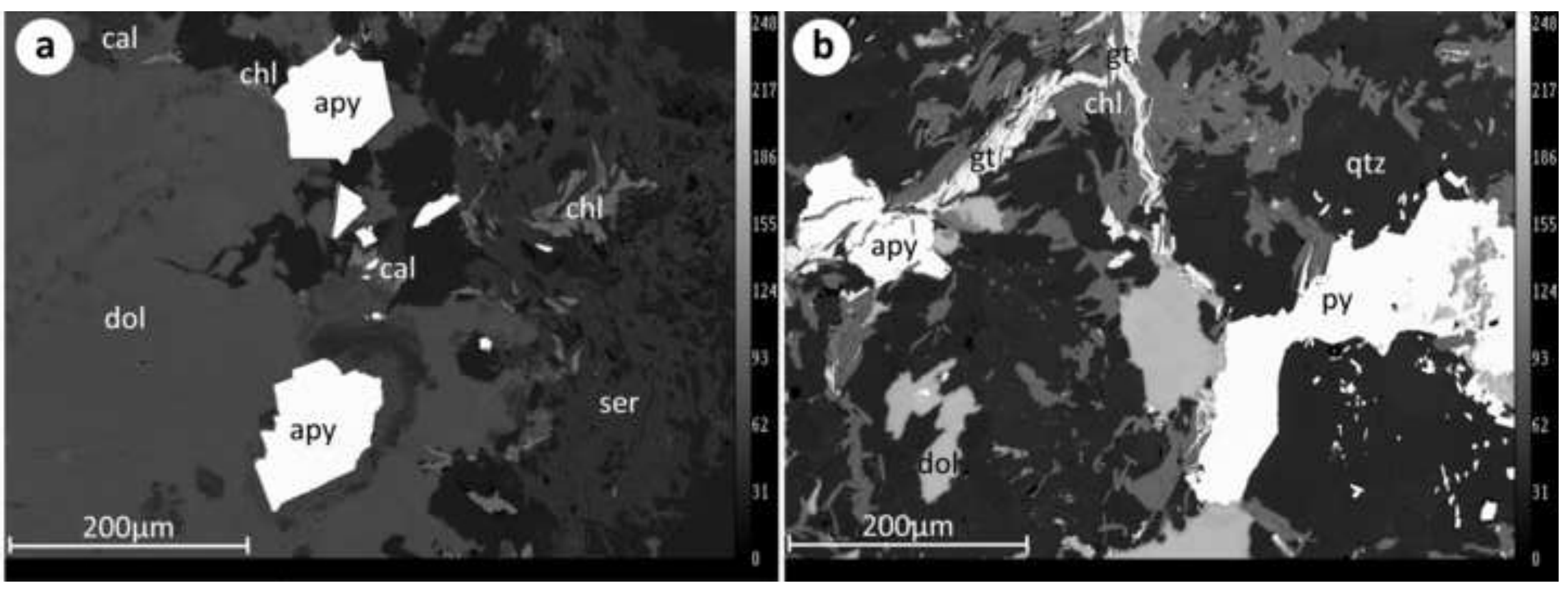



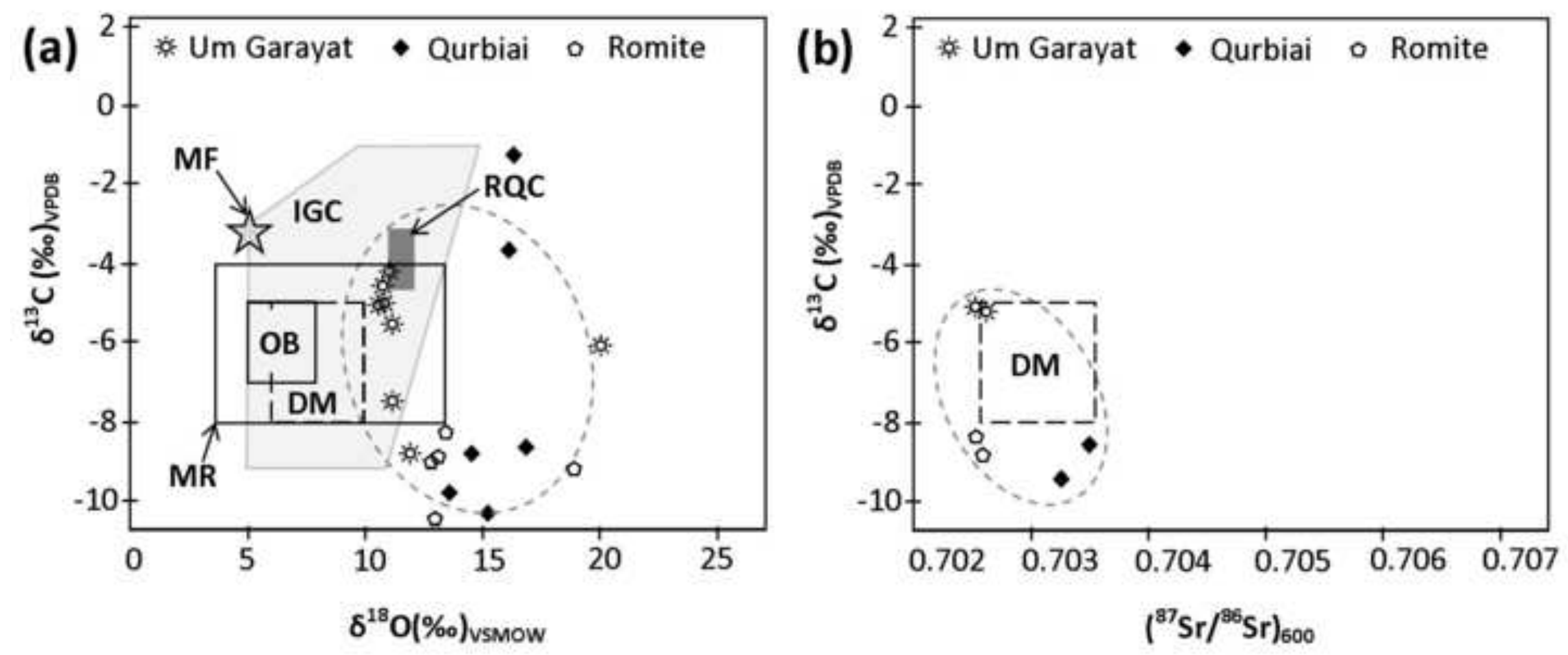
Table 1. Schematic compilation of the deformational phases, metamorphism and magmatic activities and mineralization in the Wadi Allaqi district

\begin{tabular}{|c|c|c|c|c|c|c|c|}
\hline \multicolumn{4}{|c|}{ Kusky and Ramadan (2002) } & \multirow{2}{*}{$\begin{array}{l}\text { Abdelsalam et al. (2003) } \\
\text { deformation } \\
\end{array}$} & \multirow{2}{*}{$\begin{array}{c}\text { Zoheir and Klemm (2007) } \\
\text { tectono-magmatic /mineralization }\end{array}$} & \multirow{2}{*}{ metamorphism, timing } & \multirow{2}{*}{$\begin{array}{l}\text { This study } \\
\text { Um Garayat }\end{array}$} \\
\hline deformation event & structural, magmatism & netamorphism & mineralization & & & & \\
\hline D4: Weak foliation & $\begin{array}{l}\text { - NE-striking strike } \\
\text { slip faults } \\
\text { - E-W fractures }\end{array}$ & $\begin{array}{l}\text { - dyke swarms } \\
\text { along fault zones }\end{array}$ & $\begin{array}{l}\text { - anomalous secondary } \\
\text { concentrations of } \mathrm{Pb}, \mathrm{Zr}, \mathrm{Y} \text {, } \\
\mathrm{Nb}, \mathrm{Ta} \text {, in late dykes } \\
\\
\text { - disseminated secondary } \\
\text { uranium mineralization }\end{array}$ & & $\begin{array}{l}\text { - WNW-ESE, NNE-SSW and N-S } \\
\text { joint/fracture systems cut the syn- } \\
\text { and post-orogenic granites } \\
\text { - emplacement of post-orogenic } \\
\text { intrusions }\end{array}$ & $\begin{array}{l}\text { - thermal metamorphism } \\
\text { confined to contacts with } \\
\text { post-tectonic intrusions } \\
\text { (Zoheir et al., 2017) }\end{array}$ & $\begin{array}{l}\text { - brittle defor- } \\
\text { mation of the } \\
\text { host rocks and } \\
\text { gold lodes } \\
\text {-magmatic fluid } \\
\text { overprint }\end{array}$ \\
\hline $\begin{array}{l}\text { D3: (650-550 Ma) } \\
\text { collision of east and } \\
\text { west Gondwanas; } \\
\text { tectonic escape to- } \\
\text { ward oceanic free face } \\
\text { to north along WNW } \\
\text { striking Najd faults }\end{array}$ & $\begin{array}{l}\text { - WNW-ESE and } \\
\text { NW-SE shear zones } \\
\text { and open folds, } \\
\text { crenulation cleavage, } \\
\text { SC fabrics, sigmoidal } \\
\text { foliation patterns }\end{array}$ & $\begin{array}{l}\text { - late- to post- } \\
\text { tectonic granit- } \\
\text { oids } \\
\text { - local contact } \\
\text { metamorphism }\end{array}$ & $\begin{array}{l}\text { - gold-quartz veins and } \\
\text { kaolinite alteration along } \\
\text { D3 shear zones } \\
\text { - ferrugination and silici- } \\
\text { fication of copper sulfide } \\
\text { zones }\end{array}$ & $\begin{array}{l}\text { E-W shortening } \\
\text { non-axial and non- } \\
\text { planar deformation } \\
\mathrm{N} \text {-trending upright folds } \\
\text { deform the earlier E- } \\
\text { trending folds into } \\
\text { crescentic dome inter- } \\
\text { ference patterns }\end{array}$ & $\begin{array}{l}\text { D3: E-W-compressional regime } \\
- \text { F3 major and minor folds in the } \\
\text { ophiolitic and island arc rocks } \\
\text { - local NNW-trending shear fab- } \\
\text { rics, S-C structures, and crenula- } \\
\text { tion cleavages } \\
\text { - strike slip faults } \\
\text { - emplacement of syn-orogenic } \\
\text { intrusions }\end{array}$ & $\begin{array}{l}\text { - hydrothermal activity } \\
\text { transitional between } \\
\text { brittle and ductile de- } \\
\text { formation was main } \\
\text { phase controlling gold } \\
\text { mineralization } \\
\text { (Zoheir et al., 2017) } \\
\text { - cooling age after peak } \\
\text { metamorphism (600-585 } \\
\text { Ma (Abd El-Naby and } \\
\text { Frisch 2002) }\end{array}$ & 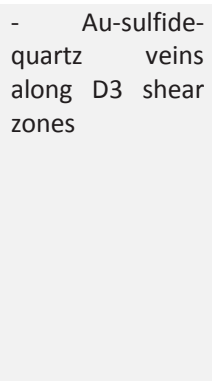 \\
\hline $\begin{array}{l}\text { D2: }(\mathbf{7 5 0 - 7 2 0} \mathrm{Ma}) \\
\text { late stages of terrance } \\
\text { collision }\end{array}$ & $\begin{array}{l}\text { - regional S-vergent } \\
\text { thrusts; imbrication } \\
\text { of arc/arc accretion- } \\
\text { ary complex }\end{array}$ & $\begin{array}{l}\text { - amphibolite in } \\
\text { D2 shear zones } \\
-\quad \text { Local high-P, } \\
\text { low- } \mathrm{T} \text { metamor- }\end{array}$ & $\begin{array}{l}\text { - remobilization of } \mathrm{Cu}- \\
\text { Ni-Pt sulfides in ultramafic } \\
\text { rocks, alteration to } \\
\text { talc/serpentinite and }\end{array}$ & $\begin{array}{l}\mathrm{N} \text {-S shortening (late) } \\
\text { E-trending upright folds } \\
\text { deform the earlier S- } \\
\text { verging structures }\end{array}$ & $\begin{array}{l}\text { D2: NE-SW transpressional regime } \\
- \text { left-lateral shearing superim- } \\
\text { posed on the thrust planes }\end{array}$ & $\begin{array}{l}\text { - peak metamorphism } \\
534-561^{\circ} \mathrm{C} \text { and } 5.3-6.2 \\
\text { kbar) } \\
\text { Peak metamorphic age } \\
650-620 \mathrm{Ma} \text { (Finger and } \\
\text { Helmy 1998) }\end{array}$ & $\begin{array}{l}\text { metamorphic } \\
\text { recrystallization } \\
\text { of arc metavol- } \\
\text { canics and bur- } \\
\text { ied VMS ores }\end{array}$ \\
\hline $\begin{array}{l}\text { D1: (750-720 Ma) } \\
\text { collision of Gerf and } \\
\text { Gabgaba arc terranes: } \\
\text { early stages }\end{array}$ & $\begin{array}{l}-\quad \text { E-W striking, } \\
\text { steeply N-dipping } \\
\text { axial planar cleavage } \\
-\quad \text { E-plunging isocli- } \\
\text { nal folds }\end{array}$ & & & $\begin{array}{l}\text { N-S shortening (late) } \\
\text { - imbricate fan nappes } \\
\text { with the emplacement } \\
\text { of thrust sheets from N } \\
\text { or NE to } S \text { or SW }\end{array}$ & $\begin{array}{l}\text { D1: crustal shortening } \\
\text { (ophiolite emplacement) } \\
\text { - fold-and-thrust belt formation } \\
\text { - overturned to recumbent folds } \\
\text { (F1) commonly verging to S or SE } \\
\text { - moderately NW-dipping thrusts } \\
\text { demark ophiolitic blocks from the } \\
\text { underlying island arc rocks. }\end{array}$ & $\begin{array}{l}\text {-low grade metamor- } \\
\text { phism } 380 \pm 50^{\circ} \mathrm{C} \\
\text { - arc-related gabbro } \\
\text { diorite, } 709 \pm 4 \mathrm{Ma} \text { (Ali et } \\
\text { al., 2010) }\end{array}$ & \\
\hline $\begin{array}{l}\text { - oceanic crust and } \\
\text { island arc formation }\end{array}$ & & & & & $\begin{array}{l}\text { - poorly preserved lamination and } \\
\text { graded bedding in the meta-tuffs }\end{array}$ & $\begin{array}{l}\text {-layered gabbro, } 730 \pm 6 \\
\text { Ma (Ali et al., 2010) }\end{array}$ & \\
\hline
\end{tabular}


ESM Table 1. Description of the investigated vein and wallrock samples

\begin{tabular}{ll}
\hline S. No. & \\
G1 & Altered meta-agglomerate, with disseminated carbonate and sericite \\
G2 & Meta-andesite (green tuffs) cut by quartz vein \\
G3 & Welded crystal tuffs with disseminated sulfides \\
G4 & Quartz vein with selvages of carbonatized tuffaceous schist and disseminated sulfides \\
G5 & Mineralized quartz vein with slivers of sulfidized/sericitized host rocks \\
G6 & Carbonatized, silicified greywacke with carbonaceous material \\
G7 & Carbonatized, silicified metasiltstone with carbonaceous material and sulfides \\
G8 & Quartz vein with abundant arsenopyrite and carbonate veinlets \\
G9 & Carbonatized and silicified metasiltstone cut by quartz vein \\
G10 & Folded meta-tuff with carbonate veins and silica pockets \\
G12 & Carbonatized chlorite schist with silica veins and disseminated sulfides \\
\hline G13 & Meta-andesite cut by quartz vein (N30 ${ }^{\circ}$ W/70 ${ }^{\circ}$ NE) \\
\hline G14 & Talc schist with silica veins and disseminated sulfides \\
G15 & Quartz vein with visible pyrite crystals \\
\hline G16 & Brecciated meta-andesite rock with fractures cemented by silica \\
G17 & Silicified crystal tuffs with dark laminae \\
\hline G18 & Schistose metasediments with abundant sericite and rutile \\
G20 & Metabasalt with carbonate patches and less common sulfides \\
G20 & Metatuffs with abundant tremolite and talc in a siliceous matix \\
G21 & Meta-agglomerates with disseminated sulfides and sericite \\
\hline G22 & Crenulated chlorite schist with disseminated sulfides and carbonaceous material \\
\hline
\end{tabular}


ESM Table 2. EPMA data and calculated formulae of pyrites and arsenopyrites from the Um Garayat deposit

\begin{tabular}{|c|c|c|c|c|c|c|c|c|c|c|c|}
\hline \multicolumn{8}{|c|}{ blocky pyrite in quartz veins } & \multicolumn{4}{|c|}{ recrystallized pyrite in host rocks } \\
\hline pyrite & G5.1 & G5.2 & G5.3 & G8.4 & G8.5 & G8.6 & G8.7 & G7.1 & G7.2 & G7.3 & G7.4 \\
\hline $\mathrm{Fe}$ & 46.88 & 47.39 & 47.35 & 47.26 & 47.14 & 46.77 & 47.32 & 46.07 & 47.3 & 47.64 & 47.28 \\
\hline S & 52.14 & 52.16 & 52.03 & 52.15 & 51.94 & 51.58 & 52.25 & 52.19 & 51.82 & 51.63 & 52.28 \\
\hline As & 0.21 & 0.29 & 0.23 & 0.12 & - & 0.16 & 0.19 & - & 0.13 & - & - \\
\hline Co & - & 0.41 & 0.11 & - & - & 0.76 & - & 0.17 & - & 0.31 & - \\
\hline $\mathrm{Ni}$ & 0.17 & - & - & - & 0.13 & - & - & 0.3 & 0.19 & 0.22 & 0.2 \\
\hline$\Sigma$ & 99.40 & 100.25 & 99.72 & 99.53 & 99.21 & 99.27 & 99.76 & 98.73 & 99.44 & 99.80 & 99.76 \\
\hline \multicolumn{12}{|c|}{ disseminated arsenopyrite in gold-bearing quartz veins } \\
\hline wt.\% & G4.1 & G4.2 & G4.3 & G5.3 & G5.2 & G5.3 & G5.4 & G5.6 & G8.1 & G8.2 & G8.3 \\
\hline $\mathrm{Fe}$ & 35.82 & 36.57 & 36.31 & 35.82 & 34.32 & 35.21 & 36.38 & 34.19 & 36.62 & 36.53 & 35.11 \\
\hline$S$ & 20.36 & 22.23 & 21.57 & 21.14 & 21.33 & 21.35 & 22.33 & 20.10 & 22.60 & 22.75 & 20.79 \\
\hline As & 44.04 & 41.61 & 42.40 & 42.71 & 42.43 & 42.65 & 40.86 & 43.96 & 40.94 & 40.59 & 43.68 \\
\hline $\mathrm{Sb}$ & - & - & - & 0.12 & 0.13 & - & 0.11 & - & - & - & - \\
\hline $\begin{array}{l}\Sigma \\
\text { at.\% }\end{array}$ & 100.22 & 100.41 & 100.28 & 99.79 & 98.21 & 99.21 & 99.68 & 98.25 & 100.16 & 99.87 & 99.58 \\
\hline $\mathrm{Fe}$ & 34.37 & 34.37 & 34.40 & 34.25 & 33.25 & 33.77 & 34.37 & 33.48 & 34.36 & 34.30 & 33.76 \\
\hline S & 34.03 & 36.40 & 35.60 & 35.21 & 36.00 & 35.67 & 36.74 & 34.29 & 36.94 & 37.21 & 34.82 \\
\hline As & 31.50 & 29.15 & 29.95 & 30.44 & 30.64 & 30.49 & 28.77 & 32.09 & 28.64 & 28.41 & 31.31 \\
\hline
\end{tabular}


ESM Table 3. EPMA data of chlorite and sericite disseminated in mineralized quartz veins in Um Garayat deposit

\begin{tabular}{|c|c|c|c|c|c|c|c|c|c|c|c|c|c|c|c|c|}
\hline \multicolumn{9}{|c|}{ chlorite in quartz veins and associated with sulfides } & \multicolumn{8}{|c|}{ sericite in quartz veins and associated with sulfides } \\
\hline $\mathrm{SiO} 2$ & 26.98 & 28.44 & 28.67 & 27.42 & 28.36 & 27.96 & 26.61 & 28.06 & $\mathrm{SiO} 2$ & 46.65 & 47.36 & 47.58 & 46.70 & 46.33 & 48.34 & 49.23 \\
\hline $\mathrm{TiO} 2$ & 0.10 & - & 0.04 & 0.05 & 0.05 & 0.06 & 0.08 & 0.07 & $\mathrm{TiO} 2$ & 0.15 & 0.21 & 0.18 & 0.10 & 0.17 & 0.23 & 0.20 \\
\hline $\mathrm{FeO}$ & 20.35 & 20.66 & 20.44 & 19.71 & 20.54 & 18.91 & 19.63 & 20.65 & $\mathrm{FeO}$ & 2.00 & 2.31 & 1.90 & 2.35 & 2.18 & 2.35 & 2.34 \\
\hline $\mathrm{MnO}$ & 0.23 & 0.25 & 0.28 & 0.25 & 0.25 & 0.24 & 0.53 & 1.00 & $\mathrm{MnO}$ & 0.04 & - & 0.04 & - & 0.03 & - & - \\
\hline $\mathrm{MgO}$ & 19.96 & 19.67 & 18.99 & 19.53 & 20.14 & 19.73 & 18.89 & 19.28 & $\mathrm{MgO}$ & 1.52 & 1.84 & 1.61 & 1.15 & 1.38 & 1.58 & 1.60 \\
\hline $\mathrm{Na} 2 \mathrm{O}$ & - & 0.02 & - & 0.05 & - & - & 0.03 & - & $\mathrm{Na} 2 \mathrm{O}$ & 0.11 & 0.15 & 0.11 & 0.14 & 0.19 & 0.27 & 0.14 \\
\hline K2O & - & - & - & - & - & - & 0.04 & 0.05 & K2O & 9.43 & 9.76 & 9.69 & 10.07 & 10.15 & 9.37 & 9.49 \\
\hline $\mathrm{BaO}$ & - & - & - & - & - & - & - & - & $\mathrm{BaO}$ & 0.10 & 0.16 & 0.20 & 0.02 & 0.07 & 0.18 & 0.08 \\
\hline $\mathrm{NiO}$ & 0.08 & 0.09 & - & 0.18 & - & 0.11 & 0.09 & 0.06 & $\mathrm{SrO}$ & - & - & - & 0.03 & 0.01 & - & - \\
\hline Cr2O3 & 0.04 & 0.08 & - & 0.10 & 0.07 & 0.07 & 0.05 & 0.04 & V203 & 0.03 & 0.05 & 0.12 & 0.04 & 0.05 & 0.13 & 0.06 \\
\hline $\mathrm{Cl}$ & 0.00 & 0.00 & 0.00 & 0.01 & 0.00 & 0.00 & 0.01 & 0.01 & Cr2O3 & - & 0.03 & 0.04 & 0.02 & - & 0.03 & - \\
\hline $\mathrm{Si}$ & 5.56 & 5.70 & 5.78 & 5.61 & 5.68 & 5.62 & 5.67 & 5.71 & $\mathrm{Si}$ & 6.34 & 6.42 & 6.42 & 6.34 & 6.29 & 6.62 & 6.69 \\
\hline $\mathrm{Ti}$ & 0.02 & 0.00 & 0.01 & 0.01 & 0.01 & 0.01 & 0.01 & 0.01 & $\mathrm{Ti}$ & 0.02 & 0.02 & 0.02 & 0.01 & 0.02 & 0.02 & 0.02 \\
\hline $\mathrm{Al}$ iv & 2.44 & 2.30 & 2.22 & 2.39 & 2.32 & 2.38 & 2.33 & 2.29 & $\mathrm{Al}(\mathrm{iv})$ & 1.66 & 1.58 & 1.58 & 1.66 & 1.71 & 1.38 & 1.31 \\
\hline Al vi & 2.29 & 2.45 & 2.53 & 2.46 & 2.39 & 2.62 & 2.30 & 2.30 & $\mathrm{Al}(\mathrm{vi})$ & 3.61 & 3.48 & 3.55 & 3.60 & 3.57 & 3.44 & 3.44 \\
\hline $\mathrm{Fe} 3+$ & 0.00 & 0.09 & 0.18 & 0.05 & 0.00 & 0.15 & 0.00 & 0.04 & $\mathrm{Al}$ & 5.27 & 5.06 & 5.13 & 5.26 & 5.28 & 4.82 & 4.76 \\
\hline $\mathrm{Fe} 2+$ & 3.56 & 3.37 & 3.26 & 3.32 & 3.39 & 3.03 & 3.49 & 3.47 & $\mathrm{Fe}(\mathrm{ii})$ & 0.23 & 0.26 & 0.21 & 0.27 & 0.25 & 0.27 & 0.27 \\
\hline $\mathrm{Mn}$ & 0.04 & 0.04 & 0.05 & 0.04 & 0.04 & 0.04 & 0.09 & 0.17 & $\mathrm{Mn}$ & 0.00 & 0.00 & 0.00 & 0.00 & 0.00 & 0.00 & 0.00 \\
\hline $\mathrm{Mg}$ & 6.14 & 5.87 & 5.70 & 5.96 & 6.02 & 5.91 & 6.00 & 5.85 & $\mathrm{Mg}$ & 0.31 & 0.37 & 0.32 & 0.23 & 0.28 & 0.32 & 0.32 \\
\hline $\mathrm{Ca}$ & 0.02 & 0.01 & 0.00 & 0.02 & 0.00 & 0.01 & 0.00 & 0.00 & $\mathrm{Ca}$ & 0.00 & 0.00 & 0.00 & 0.01 & 0.02 & 0.00 & 0.00 \\
\hline $\mathrm{Na}$ & 0.00 & 0.02 & 0.00 & 0.04 & 0.00 & 0.02 & 0.03 & 0.00 & $\mathrm{Na}$ & 0.03 & 0.04 & 0.03 & 0.04 & 0.05 & 0.07 & 0.04 \\
\hline
\end{tabular}




\begin{tabular}{|c|c|c|c|c|c|c|c|c|c|c|c|c|c|c|c|c|}
\hline $\mathrm{Ba}$ & 0.00 & 0.00 & 0.00 & 0.00 & 0.00 & 0.00 & 0.00 & 0.00 & $\mathrm{Ba}$ & 0.01 & 0.01 & 0.01 & 0.00 & 0.00 & 0.00 & 0.00 \\
\hline $\mathrm{Ni}$ & 0.02 & 0.00 & 0.00 & 0.03 & 0.00 & 0.02 & 0.00 & 0.01 & $\mathrm{Sr}$ & 0.00 & 0.00 & 0.00 & 0.00 & 0.00 & 0.00 & 0.00 \\
\hline $\mathrm{Cr}$ & 0.00 & 0.01 & 0.00 & 0.02 & 0.00 & 0.01 & 0.00 & 0.01 & $\mathrm{~V}$ & 0.00 & 0.01 & 0.01 & 0.00 & 0.01 & 0.01 & 0.01 \\
\hline $\mathrm{Cl}$ & 0.00 & 0.00 & 0.00 & 0.00 & 0.00 & 0.00 & 0.00 & 0.01 & $\mathrm{Cr}$ & 0.00 & 0.00 & 0.00 & 0.00 & 0.00 & 0.00 & 0.00 \\
\hline $\mathrm{Fe} / \mathrm{Fe}+\mathrm{Mg}$ & 0.37 & 0.37 & 0.38 & 0.36 & 0.36 & 0.35 & 0.37 & 0.38 & $\mathrm{Fe} / \mathrm{Fe}+\mathrm{Mg}$ & 0.42 & 0.41 & 0.40 & 0.53 & 0.47 & 0.45 & 0.45 \\
\hline Variety & \multicolumn{4}{|c|}{ ripidolite } & \multicolumn{4}{|c|}{ pycnochlorite } & & & & & & & & \\
\hline $\mathrm{T}\left({ }^{\circ} \mathrm{C}\right) 1$ & 304 & 289 & 282 & 298 & 291 & 296 & 292 & 288 & & & & & & & & \\
\hline $\mathrm{T}\left({ }^{\circ} \mathrm{C}\right) 2$ & 306 & 281 & 300 & 284 & 279 & 292 & 299 & 280 & & & & & & & & \\
\hline
\end{tabular}

below detection limit

$T^{\circ} \mathrm{C} 1$ = Kranidiotis and Maclean (1987), $T^{\circ} \mathrm{C} 2=$ Chlorite temperatures applying eq. 38 in Lanari et al. (2014) 
ESM Table 4. EPMA data of carbonate minerals disseminated in mineralized quartz veins in Um Garayat deposit

\begin{tabular}{|c|c|c|c|c|c|c|c|c|c|c|c|c|}
\hline \multicolumn{5}{|l|}{ calcite } & \multicolumn{8}{|c|}{ Ferrodolomite } \\
\hline $\mathrm{CaO}$ & 51.33 & 49.79 & 51.16 & 49.89 & $\mathrm{CaO}$ & 25.37 & 27.12 & 26.74 & 26.65 & 24.41 & 28.23 & 26.26 \\
\hline $\mathrm{MgO}$ & 0.70 & 0.38 & 1.19 & 1.05 & $\mathrm{MgO}$ & 15.48 & 17.87 & 17.80 & 15.61 & 16.95 & 17.37 & 16.04 \\
\hline $\mathrm{FeO}$ & 0.74 & 0.61 & 0.28 & 0.50 & $\mathrm{FeO}$ & 8.14 & 4.41 & 4.54 & 6.03 & 8.11 & 5.18 & 5.91 \\
\hline $\mathrm{MnO}$ & 0.33 & 0.30 & 0.12 & 0.20 & $\mathrm{MnO}$ & 0.14 & 0.12 & 0.18 & 0.18 & 0.14 & 0.23 & 0.15 \\
\hline $\mathrm{BaO}$ & - & - & - & 0.01 & $\mathrm{BaO}$ & 0.03 & 0.02 & - & - & 0.01 & 0.02 & 0.02 \\
\hline \multirow[t]{2}{*}{ SrO } & 0.04 & 0.10 & 0.05 & 0.05 & $\mathrm{SrO}$ & - & 0.02 & 0.06 & 0.05 & - & 0.05 & 0.05 \\
\hline & 53.14 & 51.18 & 52.78 & 51.69 & & 49.18 & 49.55 & 49.32 & 48.52 & 49.61 & 51.08 & 48.43 \\
\hline \multicolumn{5}{|c|}{ Structural formulae basis on 6 oxygens, 2 cations } & \multicolumn{8}{|c|}{ Structural formulae basis on 6 oxygens, 2 cations } \\
\hline $\mathrm{Ca}$ & 1.93 & 1.95 & 1.94 & 1.93 & $\mathrm{Ca}$ & 1.03 & 1.09 & 1.08 & 1.10 & 0.98 & 1.11 & 1.08 \\
\hline $\mathrm{Mg}$ & 0.03 & 0.01 & 0.04 & 0.04 & $\mathrm{Mg}$ & 0.63 & 0.72 & 0.72 & 0.64 & 0.68 & 0.68 & 0.66 \\
\hline $\mathrm{Fe}$ & 0.03 & 0.02 & 0.01 & 0.02 & $\mathrm{Fe}$ & 0.33 & 0.18 & 0.18 & 0.25 & 0.33 & 0.20 & 0.24 \\
\hline $\mathrm{Mn}$ & 0.01 & 0.01 & 0.00 & 0.01 & $\mathrm{Mn}$ & 0.01 & 0.00 & 0.01 & 0.01 & 0.01 & 0.01 & 0.01 \\
\hline $\mathrm{Ba}$ & 0.00 & 0.00 & 0.00 & 0.00 & $\mathrm{Ba}$ & 0.00 & 0.00 & 0.00 & 0.00 & 0.00 & 0.00 & 0.00 \\
\hline $\mathrm{Sr}$ & 0.00 & 0.00 & 0.00 & 0.00 & $\mathrm{Sr}$ & 0.00 & 0.00 & 0.00 & 0.00 & 0.00 & 0.00 & 0.00 \\
\hline sum & 2.00 & 2.00 & 2.00 & 2.00 & sum & 2.00 & 2.00 & 2.00 & 2.00 & 2.00 & 2.00 & 2.00 \\
\hline Mole\% & & & & & Mole\% & & & & & & & \\
\hline CaCO3 & 96.59 & 97.29 & 96.93 & 96.52 & $\mathrm{CaCO3}$ & 51.58 & 54.73 & 54.21 & 54.93 & 49.21 & 55.27 & 54.23 \\
\hline $\mathrm{MgCO} 3$ & 1.32 & 0.74 & 2.25 & 2.03 & MgCO3 & 31.47 & 36.06 & 36.08 & 32.16 & 34.16 & 34.01 & 33.12 \\
\hline $\mathrm{FeCO} 3$ & 1.39 & 1.18 & 0.52 & 0.96 & $\mathrm{FeCO} 3$ & 16.56 & 8.89 & 9.21 & 12.42 & 16.34 & 10.15 & 12.21 \\
\hline $\mathrm{MnCO} 3$ & 0.62 & 0.59 & 0.22 & 0.39 & MnCO3 & 0.28 & 0.24 & 0.37 & 0.37 & 0.28 & 0.45 & 0.30 \\
\hline $\mathrm{BaCO} 3$ & 0.00 & 0.00 & 0.00 & 0.01 & $\mathrm{BaCO} 3$ & 0.07 & 0.04 & 0.00 & 0.02 & 0.02 & 0.03 & 0.03 \\
\hline SrCO3 & 0.08 & 0.20 & 0.09 & 0.10 & $\mathrm{SrCO} 3$ & 0.04 & 0.04 & 0.12 & 0.10 & 0.00 & 0.09 & 0.10 \\
\hline Sum & 100.00 & 100.00 & 100.00 & 100.00 & Sum & 100.00 & 100.00 & 100.00 & 100.00 & 100.00 & 100.00 & 100.00 \\
\hline Fe\# & 0.51 & 0.61 & 0.19 & 0.32 & Fe\# & 0.34 & 0.20 & 0.20 & 0.28 & 0.32 & 0.23 & 0.27 \\
\hline $\mathrm{mg} \#$ & 0.40 & 0.30 & 0.75 & 0.60 & mg\# & 0.65 & 0.80 & 0.79 & 0.72 & 0.67 & 0.76 & 0.73 \\
\hline
\end{tabular}

below detection limit 
ESM Table 5. LA-ICP-MS data of sulfide minerals from the Um Garayat deposit

\begin{tabular}{|c|c|c|c|c|c|c|c|c|c|c|c|c|}
\hline \multirow{2}{*}{$\begin{array}{l}\text { Mineral } \\
\mathrm{n} \\
\text { Value }\end{array}$} & \multicolumn{4}{|c|}{ Recrystallized pyrite } & \multicolumn{4}{|c|}{5} & \multirow{2}{*}{$\begin{array}{c}13 \\
\text { Min }\end{array}$} & \multicolumn{3}{|c|}{ Arsenopyrite } \\
\hline & Max & Min & Ave. & StDev & Max & Min & Ave. & StDev & & Ave. & Max & StDev \\
\hline Co & 996.73 & 0.13 & 207.3 & 294.2 & 54.3 & 0.44 & 20.04 & 25.4 & 4.4 & 27.6 & 107.7 & 18.6 \\
\hline $\mathrm{Ni}$ & 1212.4 & 1.98 & 116 & 251.7 & 184.7 & 91.3 & 131 & 44.4 & 2.7 & 12.8 & 50.2 & 22.0 \\
\hline $\mathrm{Cu}$ & 2881 & 3.09 & 165.9 & 622.6 & 1234 & 2.09 & 323.8 & 607.4 & $<$ LOD & 114.9 & 451.3 & \\
\hline $\mathrm{Zn}$ & 49.30 & 2.04 & 8.84 & 10.56 & 1338.8 & 3.43 & 274.1 & 595.2 & $<$ LOD & 2.3 & 10.2 & 2.2 \\
\hline As & 2613.7 & 25.43 & 451 & 650.9 & 3573 & 776.7 & 2170 & 1309 & & & & \\
\hline $\mathrm{Se}$ & 181 & 5.45 & 91.2 & 49.76 & 68.6 & 52.26 & 60.6 & 5.99 & 24.1 & 89.2 & 162.6 & 20.0 \\
\hline Mo & 0.32 & 0.14 & 0.26 & 0.07 & 0.18 & 0.14 & 0.16 & 0.03 & $<$ LOD & 0.5 & 2.0 & 0.0 \\
\hline $\mathrm{Ag}$ & 23.32 & 0.09 & 1.70 & 5.16 & 2.73 & 0.02 & 0.96 & 1.10 & $<\mathrm{LOD}$ & 0.1 & 0.4 & 0.4 \\
\hline $\mathrm{Sb}$ & 302.6 & 0.09 & 40.3 & 64.4 & 2.91 & 0.10 & 1.29 & 1.32 & 1.0 & 232.8 & 529.6 & 55.1 \\
\hline $\mathrm{Te}$ & 36.65 & 0.28 & 2.66 & 8.02 & 39.2 & 1.00 & 11.1 & 18.8 & 0.6 & 1.9 & 5.2 & 1.6 \\
\hline W & 0.27 & 0.01 & 0.10 & 0.08 & 0.01 & $<\mathrm{LOD}$ & & & $<$ LOD & 0.5 & 2.6 & 0.1 \\
\hline $\mathrm{Au}$ & 0.98 & 0.02 & 0.14 & 0.23 & 0.05 & 0.02 & 0.03 & 0.01 & 0.1 & 6.9 & 16.8 & 3.8 \\
\hline $\mathrm{Pb}$ & 1125 & 0.64 & 256 & 305.2 & 586.9 & 0.22 & 204.5 & 281.1 & 0.2 & 3.2 & 17.9 & 4.2 \\
\hline $\mathrm{Bi}$ & 31.14 & 0.02 & 2.68 & 6.56 & 8.33 & 0.07 & 3.14 & 4.08 & 0.4 & 2.9 & 6.3 & 3.7 \\
\hline $\begin{array}{l}\text { Mineral } \\
\mathrm{n}\end{array}$ & 7 & Pyrr & hotite & & 4 & Chalc & opyrite & & & & & \\
\hline Value & Max & Min & Average & StDev & Max & Min & Average & StDev & & & & \\
\hline Co & 44.9 & 2.3 & 14.8 & 18.6 & 138.9 & 0.2 & 34.9 & 69.3 & & & & \\
\hline $\mathrm{Ni}$ & 88.6 & 23.5 & 44.4 & 22.0 & 17.2 & $<\mathrm{LOD}$ & 6.5 & 9.2 & & & & \\
\hline $\mathrm{Cu}$ & 2.2 & $<$ LOD & & & $<$ LOD & & & & & & & \\
\hline $\mathrm{Zn}$ & 6.8 & $<$ LOD & 2.5 & 2.2 & 1109.0 & 174.7 & 640.7 & 429.2 & & & & \\
\hline As & 1696.1 & $<$ LOD & 471.0 & 688.4 & 496.3 & $<$ LOD & 400.0 & 85.4 & & & & \\
\hline $\mathrm{Se}$ & 79.5 & 29.3 & 44.4 & 20.0 & 105.6 & 22.8 & 47.7 & 38.8 & & & & \\
\hline Mo & 0.4 & $<$ LOD & 0.4 & 0.0 & 0.8 & $<$ LOD & 0.5 & 0.3 & & & & \\
\hline $\mathrm{Ag}$ & 0.9 & $<$ LOD & 0.4 & 0.4 & 9.8 & 1.4 & 3.6 & 4.2 & & & & \\
\hline $\mathrm{Sb}$ & 96.1 & $<$ LOD & 32.6 & 55.1 & 81.4 & $<$ LOD & 27.4 & 46.8 & & & & \\
\hline $\mathrm{Te}$ & 4.0 & $<$ LOD & 2.1 & 1.6 & 21.5 & 1.9 & 7.2 & 9.5 & & & & \\
\hline W & 0.3 & $<$ LOD & 0.2 & 0.1 & 0.0 & $<$ LOD & & & & & & \\
\hline $\mathrm{Au}$ & 0.0 & $<$ LOD & & & 14.5 & $<$ LOD & & & & & & \\
\hline $\mathrm{Pb}$ & 9.8 & 0.1 & 3.1 & 4.2 & 117.2 & 0.2 & 30.7 & 57.7 & & & & \\
\hline $\mathrm{Bi}$ & 8.7 & $<\mathrm{LOD}$ & 2.2 & 3.7 & 66.2 & $<$ LOD & 16.6 & 33.1 & & & & \\
\hline
\end{tabular}


ESM Table 6. Sulfur isotope values of sulfide mineral from the Um Garayat gold deposit

\begin{tabular}{|c|c|c|c|c|c|c|}
\hline \multirow[t]{2}{*}{ Sample description/GPS location } & Spot & $32 \mathrm{~S}(\mathrm{v})$ & $\delta^{34} \mathrm{~S} \%$ (V-CDT) & $2 \mathrm{~s}$ & Mineral & Comments \\
\hline & \multicolumn{6}{|c|}{ (blocky pyrite and pyrrhotite) } \\
\hline \multirow{4}{*}{$\begin{array}{l}\text { Quartz vein with carbonatized } \\
\text { tuffaceous slivers and sulfides }\end{array}$} & G4-1-1 & 0.91 & 2.0 & 0.21 & Po & inner replacement zone \\
\hline & G4-b-1 & 0.88 & 2.3 & 0.25 & Po & Po tail on Asp crystal \\
\hline & G4-b-2 & 1.52 & 2.4 & 0.18 & Py & large euhedral crystal \\
\hline & G4-2-1 & 1.49 & 2.3 & 0.17 & Py & isolated euhedral crystal \\
\hline \multirow{2}{*}{ Lat. $22^{\circ} 34^{\prime} 20^{\prime \prime} \mathrm{N}$} & G4-3-1 & 1.50 & 3.7 & 0.17 & Py & subhedral pyrite crystal \\
\hline & G4-4-1 & 0.59 & 2.9 & 0.23 & Po & irregular tail on Asp crystal \\
\hline \multirow{2}{*}{ Long. $33^{\circ} 22^{\prime} 25^{\prime \prime} \mathrm{E}$} & G4-5-1 & 1.12 & 2.6 & 0.16 & Po & isolated subhedral crystal \\
\hline & G4-5-2 & 1.09 & 1.6 & 0.19 & Po & replacement rim on Asp crystal \\
\hline \multirow{4}{*}{$\begin{array}{l}\text { Quartz vein with host rock mate- } \\
\text { rials }\end{array}$} & G5-1-1 & 1.28 & 2.0 & 0.26 & Po & large isolated Po crystal \\
\hline & G5-1-2 & 1.16 & 2.6 & 0.21 & Po & large isolated Po crystal \\
\hline & G5-2-1 & 1.54 & 2.1 & 0.17 & Py & core of an euhedral Py crystal \\
\hline & G5-2-2 & 1.60 & 3.3 & 0.14 & Py & rim of large euhedral Py crystal \\
\hline \multirow{2}{*}{ Lat. $22^{\circ} 34^{\prime} 21^{\prime \prime} \mathrm{N}$} & G5-2-3- & 1.01 & 2.4 & 0.23 & Py & irregular replacement of Py \\
\hline & G5-3-1 & 0.97 & 1.7 & 0.24 & Po & rim on subhedral Py crystal \\
\hline \multirow[t]{4}{*}{ Long. $33^{\circ} 22^{\prime} 34^{\prime \prime} \mathrm{E}$} & G5-5-1 & 0.62 & 2.6 & 0.20 & Po & replacement on large Py crystal \\
\hline & \multicolumn{6}{|c|}{ (recrystallized pyrite) } \\
\hline & G7-1-1 & 1.70 & -9.9 & 0.16 & Py & core of aggregated crystals \\
\hline & G7-1-2 & 1.58 & -10.0 & 0.15 & Py & subhedral crsytal in aggregates \\
\hline \multirow{4}{*}{$\begin{array}{l}\text { Carbonatized metasiltstone } \\
\text { with disseminated sulfides and } \\
\text { carbonaceous laminae }\end{array}$} & G7-1-3 & 1.75 & -10.1 & 0.19 & Py & core of smaller euhedral crystal \\
\hline & G7-2-1 & 1.72 & -9.3 & 0.19 & Py & massive rim of a large pyrite \\
\hline & G7-2-2 & 1.79 & -10.0 & 0.18 & Py & rim of aggregated grains with $\mathrm{Cpy}$ \\
\hline & G7-3-1 & 1.87 & -9.4 & 0.16 & Py & core of aggregated pyrite \\
\hline Lat. $22^{\circ} 34^{\prime} 14^{\prime \prime} \mathrm{N}$ & G7-3-2 & 1.92 & -9.0 & 0.18 & Py & rim of same aggregate as G7-3.1 \\
\hline \multirow{4}{*}{ Long. $33^{\circ} 22^{\prime} 35^{\prime \prime} \mathrm{E}$} & G7-4-1 & 1.61 & -10.6 & 0.36 & Py & rim of euhedral crystal \\
\hline & G7-4-2 & 1.84 & -9.8 & 0.17 & Py & core of same euhedral grain \\
\hline & G7-6-1 & 1.41 & -10.0 & 0.18 & Py & subhedral recrystallized pyrite \\
\hline & G7-6-2 & 1.71 & -10.0 & 0.18 & Py & marginal part of recrystallized Py \\
\hline
\end{tabular}


ESM Table 7. Sr, C and O isotopic data for carbonate samples from the Um Garayat, Romite and Qurbiai gold deposits

\begin{tabular}{|c|c|c|c|c|c|c|c|c|c|c|c|}
\hline \multirow[b]{2}{*}{ Sample } & \multicolumn{5}{|c|}{ Concentrations (ppm)a } & \multirow{2}{*}{$\begin{array}{l}\delta^{18} 0 \\
(\% \text { VSMOW) }\end{array}$} & \multirow{2}{*}{$\begin{array}{l}\delta^{13} \mathrm{C} \\
(\% \text { VPDB) }\end{array}$} & $\delta^{18} 0$ & $\delta^{13} \mathrm{C}$ & $\delta^{18} 0$ & $\delta^{13} \mathrm{C}$ \\
\hline & $\mathrm{Rb}$ & $\mathrm{Sr}$ & ${ }^{87} \mathrm{Rb} /{ }^{86} \mathrm{Sr}$ & ${ }^{87} \mathrm{Sr} /{ }^{86} \mathrm{Sr}( \pm 2 \mathrm{SE})$ & $\left({ }^{87} \mathrm{Sr} /{ }^{86} \mathrm{Sr}\right) 600^{\mathrm{b}}$ & & & \multicolumn{2}{|c|}{ eq. fluid at $300^{\circ} \mathrm{C}$} & \multicolumn{2}{|c|}{ eq. fluid at $280^{\circ} \mathrm{C}$} \\
\hline G2 & & & & & & 11.9 & -8.8 & 4.4 & -3.8 & 3.7 & -4.0 \\
\hline G5a & 0.072 & 18.55 & 0.01123 & $0.70256 \pm 0.000014$ & 0.70247 & 10.5 & -5.0 & 4.6 & -3.2 & 3.9 & -3.5 \\
\hline G5c & & & & & & 10.8 & -4.5 & 4.9 & -2.9 & 4.2 & -3.2 \\
\hline G5d & & & & & & 11.0 & -4.2 & 4.7 & -3.7 & 4.0 & -4.0 \\
\hline G6a & 0.023 & 58.72 & 0.00113 & $0.70245 \pm 0.000013$ & 0.70245 & 10.8 & -5.0 & 4.4 & -3.7 & 3.7 & -4.0 \\
\hline G7a & & & & & & 10.5 & -5.0 & 5.1 & -4.2 & 4.4 & -4.5 \\
\hline G7c & & & & & & 11.2 & -5.5 & 5.0 & -6.2 & 4.3 & -6.5 \\
\hline G7d & & & & & & 11.1 & -7.5 & 5.8 & -7.5 & 5.1 & -7.8 \\
\hline G9 & & & & & & 20.2 & -5.9 & 14.0 & -4.6 & 13.3 & -4.9 \\
\hline R1 & & & & & & 19.1 & -8.8 & & & & \\
\hline $\mathrm{R} 2$ & 0.015 & 32.17 & 0.00135 & $0.70264 \pm 0.000015$ & 0.70263 & 13.4 & -8.3 & & & & \\
\hline R3 & 0.004 & 20.95 & 0.00055 & $0.70256 \pm 0.000013$ & 0.70256 & 12.8 & -9.1 & & & & \\
\hline $\mathrm{R} 4$ & & & & & & 12.7 & -10.6 & & & & \\
\hline $\mathrm{R} 5$ & & & & & & 13.1 & -8.9 & & & & \\
\hline C1-1 & & & & & & 16.5 & -1.3 & & & & \\
\hline $\mathrm{C} 1-2$ & & & & & & 16.3 & -3.8 & & & & \\
\hline
\end{tabular}


C5

0.286

11.98

0.06907

$0.70427 \pm 0.000016$

0.70368

16.9

14.5

15.2

13.5

0.70325

0.005

83.81

0.00017

$0.70325 \pm 0.000017$
9

$-8.7$

C5p

C11

a Blank-corrected concentrations.

b Isotopic composition at $600 \mathrm{Ma}$.

Fractionation equations of dolomite-water and dolomite- $\mathrm{CO}_{2}$ are from Matthews and Katz (1977) and Ohmoto and Rye (1979), respectively.

Isotope data of carbonate from Romite (R) and Qurbiai (c) gold deposits are given for comparison.
$-8.7$

$-10.3$

$-9.8$ 